\title{
Structure and function of the human Gly1619Arg polymorphism of M6P/IGF2R domain 11 implicated in IGF2 dependent growth
}

\author{
Dellel Rezgui, Christopher Williams ${ }^{1}$, Sharon A Savage ${ }^{2}$, Stuart N Prince, Oliver J Zaccheo, \\ E Yvonne Jones ${ }^{3}$, Matthew P Crump ${ }^{1}$ and A Bassim Hassan \\ Cancer Research UK Tumour Growth Control Group, Weatherall Institute of Molecular Medicine, John Radcliffe Hospital, University of Oxford, Headington, Oxford OX3 9DS, UK \\ ${ }^{1}$ Department of Organic and Biological Chemistry, School of Chemistry, University of Bristol, Bristol BS8 1TS, UK \\ ${ }^{2}$ Division of Cancer Epidemiology and Genetics, National Cancer Institute, 6120 Executive Boulevard, EPS/7018, Rockville, Maryland 20852, USA \\ ${ }^{3}$ Cancer Research UK Receptor Structure Research Group, Division of Structural Biology, Wellcome Trust Centre for Human Genetics, University of Oxford, Oxford OX3 7BN, UK
}

(Correspondence should be addressed to A B Hassan; Email: bass.hassan@imm.ox.ac.uk)

\begin{abstract}
The mannose 6-phosphate/IGF 2 receptor (IGF2R) is comprised of 15 extra-cellular domains that bind IGF2 and mannose 6-phosphate ligands. IGF2R transports ligands from the Golgi to the pre-lysosomal compartment and thereafter to and from the cell surface. IGF2R regulates growth, placental development, tumour suppression and signalling. The ligand IGF2 is implicated in the growth phenotype, where IGF2R normally limits bioavailability, such that loss and gain of IGF2R results in increased and reduced growth respectively. The IGF2R exon 34 (5002A > G) polymorphism (rs629849) of the IGF2 specific binding domain has been correlated with impaired childhood growth (A/A homozygotes). We evaluated the function of the Gly1619Arg non-synonymous amino acid modification of domain 11. NMR and X-ray crystallography structures located 1619 remote from the ligand binding region of domain 11 . Arg1619 was located close to the fibronectin type II (FnII) domain of domain 13, previously implicated as a modifier of IGF2 ligand binding through indirect interaction with the AB loop of the binding cleft. However, comparison of binding kinetics of IGF2R, Gly1619 and Arg1619 to either IGF2 or mannose 6-phosphate revealed no differences in 'on' and 'off' rates. Quantitative PCR, ${ }^{35} \mathrm{~S}$ pulse chase and flow cytometry failed to demonstrate altered gene expression, protein half-life and cell membrane distribution, suggesting the polymorphism had no direct effect on receptor function. Intronic polymorphisms were identified which may be in linkage disequilibrium with rs629849 in certain populations. Other potential IGF2R polymorphisms may account for the correlation with childhood growth, warranting further functional evaluation.
\end{abstract}

Journal of Molecular Endocrinology (2009) 42, 341-356

\section{Introduction}

The human mannose 6-phosphate/IGF2 receptor (IGF2R) is a large $(270 \mathrm{kDa})$ multi-functional type I membrane protein and $P$-type lectin. The 15 extracellular domains of IGF2R bind ligands that are shuttled from the Golgi to the pre-lysosomal compartment and thereafter to and from the cell surface (Ghosh et al. 2003). Functional studies in mouse models have shown that IGF2R ligands are involved in embryonic growth, placental development, tumour suppression and signalling.

Mannose 6-phosphate bound to domains 3,5 and 9 regulates the transport of phosphomannosyl glycoproteins such as lysosomal proteases, and latent transforming growth factor $\beta 1$ (latent-TGF $\beta 1$ ), where activation of the latter to active TGF $\beta 1$ occurs by proteolytic cleavage (Dennis and Rifkin 1991, Hancock et al. 2002a, $b$, Ghosh et al. 2003). IGF 2 (IGF2) binds to domain 11 of mammalian IGF2R with high affinity and specificity $\left(\sim 10^{-10} \mathrm{M}\right)$, with a fibronectin type II region of domain 13 thought to act as an indirect enhancer of affinity through reduction in 'off rate' (Linnell et al. 2001, Williams et al. 2007, Brown et al. $2008)$. IGF2 is a small hydrophobic ligand $(7 \cdot 5 \mathrm{kDa})$ that is normally bound to binding proteins (IGFBP's) that regulate bioavailability through proteolytic cleavage. For example, the potent embryonic growth promoting effect of IGF2 depends on the expression of a developmentally expressed protease, PAPPA2, that cleaves binding proteins to release free IGF2 for signal activation (Conover et al. 2004). The binding stochiometry of IGF2 to membrane bound IGF2R is $1: 1$, and utilises the same binding site on IGF2 that is recognised by binding proteins (Brown et al. 2008). IGF2R sequesters free IGF2 ligand and internalises it for intracellular degradation, and so limits activation of the signalling receptors IGF1R and isoform A of the insulin 
receptor (Foulstone et al. 2005). In the mouse, loss of function of IGF2R results in disproportionate embryonic overgrowth and perinatal lethality that was rescued by the combination with knockout of $I g f 2$ (Wang et al. 1994, Ludwig et al. 1996). Moreover, loss of function of IGF2R has been observed in human tumours through loss of heterozygosity and functional missense mutations, with genetic models that also confirm the Igf2 dependency of tumours (Christofori et al. 1994, De Souza et al. 1995, Hankins et al. 1996, Devi et al. 1999, Kong et al. 2000, Harper et al. 2006). These results suggest that the growth antagonist effects of IGF2R are principally determined by the reduction in free IGF2 ligand supply.

The relative abundance of IGF2 and IGF2R are also regulated at the level of gene expression through genomic imprinting. In all mammals, IGF2 is a maternally silenced (imprinted) gene, with paternal allele expression, whereas IGF2R is normally paternally silenced, with maternal allele expression. Unlike other mammals, IGF2R imprinting in humans is a polymorphic trait, with most individuals having bi-allelic expression that in the mouse results in growth retardation (Kalscheuer et al. 1993, Xu et al. 1993, Wutz et al. 2001). Germ line loss of imprinting of IGF2 has been reported to occur in up to $10 \%$ of humans and may be associated with an increased risk of colorectal cancer (Cui et al. 2003, Ito et al. 2008). Observational data have also correlated blood concentrations of IGF2 and soluble IGF2R with human birth weight and adult height, suggesting that relative supply of ligand and receptor may result in significant growth effects (Ong et al. 2000, Garrone et al. 2002).

Aside from imprinting, functional dosage of IGF2R may also be modified by polymorphisms that either alters gene expression or protein function. For example, epigenetic mediated reduction in IGF2R expression in cloned sheep accounted for the 'large offspring syndrome' phenotype (Young et al. 2001). Single nucleotide polymorphisms have been identified throughout the $140 \mathrm{~Kb}$ locus and the 48 exons and introns of human IGF2R (Killian et al. 2001). Nonsynonymous polymorphisms in coding exons have been mapped to specific domains of the protein. For example, the exon 34 (5002A>G) Gly1619Arg polymorphism generates a non-synonymous modification of domain 11 of IGF2R, and exists in Hardy Weinberg equilibrium in humans (allele frequencies $A=0 \cdot 15$, $G=0.85$; Killian et al. 2001). Analysis of the Avon Longitudinal Study of Parents and Children prospective cohort of normal mothers and children suggested that babies born with the rarer AA homozygote alleles exhibited slower growth rate kinetics during the first three years of post-natal development, even though circulating IGF2 levels were similar to GG homozygotes and heterozygote controls (Petry et al. 2005).
A comprehensive analysis of SNPs associated with the later development of cancer has been recently reported with IGF2R haplotypes identified that conferred an increased risk of developing osteosarcoma (Savage $e t a l$. 2007). In this example, an intron 16 SNP was associated with loss of methylation of a $\mathrm{CpG}$ island site that presumably controlled gene expression. The implications of these, and similar SNP association studies, are limited by the lack of functional analysis of associated SNPs, in particular non-synonymous SNPs in ligand binding domains of IGF2R. Here, we report the first comprehensive functional analysis of a non-synonymous IGF2R polymorphism, Gly1619Arg of domain 11, the domain that specifically binds IGF2. We demonstrate that this polymorphism alone has no detectable effects on domain 11 structure, real-time ligand binding kinetics, protein half-life and cell surface distribution. We discuss the implications of these findings with respect to IGF2R function and linkage to other SNPs.

\section{Material and Methods}

\section{Plasmids, cloning and reagents}

For rat CD4 domains 3 and 4 -IGF2R chimeric constructs (CD4-IGF2R), previously described pEFBOS plasmids containing IGF2R domains $11,10-13$ and 1-15 were utilised (Linnell et al. 2001, Zaccheo et al. 2006). For membrane-bound IGF2R, full IGF2R insert was derived from ATCC (J03528) using primers (FullIGF2RNheIF2) 5'-atatgctagcGCGATGGGGGCCGCCGCC-3' and (FullIGF2RXhoIR2) $5^{\prime}$-gcgcctcgagTCAGATGTGTAAGAGGTCCTCGTCG-3' ${ }^{\prime}$, incorporating NheI and XhoI restriction sites respectively. The product was ligated into the pcDNA $3 \cdot 1(+)$ vector to generate pcDNA-IGF2R. pEGFP-N1 plasmid was from Clontech (Saint-Germain-en-Laye, France). Protein biotinylation was performed using the BirA biotinprotein ligase from Avidity (CO, USA). Recombinant human IGF2 was from Novozymes GroPep Ltd., (Adelaide, Australia) and latent-TGF $\beta 1$ was from R\&D systems (Abingdon, UK). L- $\left[{ }^{35} \mathrm{~S}\right]$ methionine and $\mathrm{L}-\left[{ }^{35} \mathrm{~S}\right]$ cysteine Redivue Pro-Mix (Radioactive concentration $370 \mathrm{MBq} / \mathrm{ml}(10 \mathrm{mCi} / \mathrm{ml})$ with respect to $\mathrm{L}-\left[{ }^{35} \mathrm{~S}\right]$ methionine at the activity reference date were obtained from Amersham. Methionine/Cysteine-free DMEM and Protein G-Sepharose beads were from Sigma. Mouse anti rat-CD4 antibody (MCA1022R) and mouse anti human-IGF2R (MCA2048) were from AbD Serotec (Oxford, UK), goat anti-mouse PE/Cy5 (M32006) was from Caltag Laboratories (Invitrogen) and rabbit anti-E-cadherin was from Santa Cruz Biotechnology Inc., (Heidelberg, Germany). QuickChange II Site-directed Mutagenesis kit was from 
Stratagene (Cheshire, UK) and Phusion Site-directed Mutagenesis kit was from Finnzymes (Espoo, Finland). ImProm-II reverse transcription system was from Promega. Surface plasmon resonance (SPR) buffers, chips and consumables were from GE Healthcare (BIAcore, Chalfont, UK). The FACSCalibur system used for flow cytometry was from Becton Dickinson (Oxford, UK).

\section{Site-directed mutagenesis}

In the pEFBOS plasmids, Gly1619Arg mutant constructs were generated using the Quick-Change II kit according to the manufacturer's protocols, using primers (G1619R F) 5'-CGTGTGCAGGCCTGAGGCCAGGCCAACCAATAGGCC-3' and (G1619R R) 5'-GGCCTATTGGTTGGCCTGGCCTCAGGCCTGCACACG-3'. For IGF2R domains $11,10-13$ and 1-15 these are termed CD4-11, CD4-10-13 and CD4-1-15. In the pcDNA-IGF2R plasmid, Gly1619Arg mutant constructs were generated using the Phusion kit according to the manufacturer's protocols, using primers (G1619R-phus-F) 5'-GCCAGGCCAACCAATAGGCCCATGCTCATCT-3' and (G1619R-phus-R) 5'-CTCAGGCCTGCACACGAAACTGATCACACTC- ${ }^{\prime}$. The mutations were confirmed by DNA bi-directional sequencing performed by the sequencing service (School of Life Sciences, University of Dundee, Scotland) using Applied Biosystems Big-Dye Version 3.1 chemistry on an Applied Biosystems model 3730 automated capillary DNA sequencer.

\section{IGF2R domain 11 G1619R}

To construct IGF2R domain 11 Gly1619Arg expression vector, domain 11 Gly1619Arg was amplified by PCR from pEFBOS-IGF2R-domain11 Gly1619Arg and cloned into the NdeI and $\mathrm{XhoI}$ restriction sites of pET26b (Novagen) using standard methods. The authenticity of the clones was verified by sequencing. Wild-type domain 11 had been previously cloned into pET22b for Escherichia coli expression (Brown et al. 2002). ${ }^{15} \mathrm{~N}$-labelled wild-type and Gly1619Arg domain 11 were expressed in E. coli BL21(DE3) grown in M9 media supplemented with $1 \mathrm{~g} / 1$ of ${ }^{15} \mathrm{NH}_{4} \mathrm{Cl}$ as the sole nitrogen source and refolded using established protocols (Williams et al. 2007). Owing to slightly different cloning strategies, wild-type domain 11 had a C-terminal hexahistidine tag while the Gly1619Arg domain 11 construct lacked any additional amino acids.

\section{NMR spectroscopy}

NMR samples typically contained $\sim 250 \mu \mathrm{M}$ protein dissolved in $600 \mu \mathrm{l}$ of $20 \mathrm{mM}$ sodium acetate (pH5.5),
$1 \mathrm{mM}$ EDTA, $1 \mathrm{mM}$ benzamidine and $100 \mu \mathrm{M} \mathrm{NaN} \mathrm{N}_{3}$ in $95 \% \mathrm{H}_{2} \mathrm{O} / 5 \% \mathrm{D}_{2} \mathrm{O}$. Two dimensional ${ }^{1} \mathrm{H}_{-}{ }^{15} \mathrm{~N}$ heteronuclear single quantum coherence spectra were recorded at $25^{\circ} \mathrm{C}$ on a Varian $600 \mathrm{MHz}$ INOVA spectrometer equipped with a triple resonance probe. Spectra were acquired with $1024{ }^{1} \mathrm{H}$ complex points in the $\mathrm{t} 2$ dimension and 128 points in the ${ }^{15} \mathrm{~N}$ dimension, and spectral widths of $7000 \mathrm{~Hz}$ in ${ }^{1} \mathrm{H}$ and $2000 \mathrm{~Hz}$ in ${ }^{15} \mathrm{~N}$. Data were processed using NMRPipe (Delaglio et al. 1995) and analysed with CCPN Analysis version 1.015 (Vranken et al. 2005).

\section{Expression of CD4-IGF2R chimeras and membrane bound IGF2R}

The CD4-IGF2R chimeric constructs were transiently expressed in 293T cells using Fugene 6.0 (Roche). Briefly, $4 \mu \mathrm{g}$ DNA and in a 6:1 plasmid:Fugene ratio were added to cells and grown for 5 days in serum free media (DMEM; Sigma-D5796) with $4500 \mathrm{mg} / \mathrm{l}$ glucose, L-glutamine $(584 \mathrm{mg} / \mathrm{l}), \mathrm{NaHCO}_{3}(3 \cdot 7 \mathrm{~g} / \mathrm{l})$ and pyrodoxyl $\mathrm{HCl}(4 \mathrm{mg} / \mathrm{l})$ with added $50 \mathrm{u} / \mathrm{ml}$ penicillin, $50 \mu \mathrm{g} / \mathrm{ml}$ streptomycin. Spent culture supernatants were collected, and cells were cleared by centrifugation. Cell lysis and recombinant CD4-IGF2R chimeras' detection was with a CD4 sandwich ELISA as described (Davis et al. 1990). Protein biotinylation, SDS PAGE and western blotting were also performed as previously described (Linnell et al. 2001, Zaccheo et al. 2006). The full length IGF2R constructs were transiently co-expressed in 293T cells with eGFP plasmid using lipofectamine $(10 \mu \mathrm{l})$ (Invitrogen) using $3 \cdot 6 \mu \mathrm{g}$ pcDNA-IGF2R and $0.4 \mu \mathrm{g}$ eGFP-N1 plasmid in antibiotic-free growth media (DMEM with $2 \mathrm{mM}$ glutamine and $10 \%$ fetal bovine serum). The medium was changed $24 \mathrm{~h}$ posttransfection to serum-free medium, and cells were prepared for flow cytometry $48 \mathrm{~h}$ post-transfection.

\section{Surface plasmon resonance kinetic analysis}

Kinetic analysis by SPR was conducted as previously described (Zaccheo et al. 2006) using a BIAcore 3000 biosensor (BIAcore). All SPR experiments were performed at $25^{\circ} \mathrm{C}$ in HBS-EP (10 mM Hepes (pH 7.4), $150 \mathrm{mM} \mathrm{NaCl}, 3 \mathrm{mM}$ EDTA and $0.005 \%$ (v/v) surfactant P20) at a flow-rate of $40 \mu \mathrm{l} / \mathrm{min}$. After pre-conditioning, the sensor chip with three $1 \mathrm{~min}$ injections of $1 \mathrm{M} \mathrm{NaCl}, 50 \mathrm{mM} \mathrm{NaOH}$, either $\sim 600 \mathrm{RU}$ of recombinant biotinylated CD4-11, $1600 \mathrm{RU}$ of recombinant biotinylated CD4-10-13 or 3300 RU of recombinant biotinylated CD4-1-15 were immobilised on a Sensor Chip SA by affinity capture to streptavidin. Kinetic experiments consisted of a 2-5 min injection of analyte followed by a $150-200 \mathrm{~s}$ dissociation phase in HBS-EP running buffer, after which the binding surface 
was regenerated with a 2 min injection of $2 \mathrm{M} \mathrm{MgCl}_{2}$. Kinetic parameters were determined by global fitting of sensorgrams to a two-state (conformational change) binding model using BIA evaluation software version 4.0.1. In all cases, the minor component made an insignificant contribution to the overall affinity and, as such, only the kinetic parameters of the major binding component were used. For each interaction, the dissociation affinity constant $\left(K_{\mathrm{D}}\right)$ were also calculated by fitting of the response of each concentration at equilibrium to a steady-state affinity model using BIAevaluation.

Using the SA sensor chip with immobilised WT CD41-15 and G1619R CD4-1-15, competition assay experiments were run at a flow-rate of $40 \mu \mathrm{l} / \mathrm{min}$ and consisted of a co-inject of a first $100 \mu \mathrm{l}$ injection of either (130 nM) recombinant human IGF2 or (30 nM) latent TGF $\beta 1$, followed by a second $100 \mu$ injection of a 1:1 mixture of both analytes at the same above concentrations or 1:1 mixture of one analyte with buffer. A control experiment was run on the same sensor chip, where a co-inject of a first $100 \mu \mathrm{l}$ injection of buffer (HBS-EP), followed by a second $100 \mu \mathrm{l}$ injection of a 1:1 mixture of each analyte at the same above concentrations with buffer.

Analysis of the competition experiments were performed by quantifying the amounts of bound analyte from the second injection of each co-inject. This was assessed from the response amplitude (RU) and compared with control injections. For both kinetic and competition analyses, a blank flow-cell was used for in-line reference subtraction of changes due to differences in refractive index of running buffer versus sample and a buffer-only injection was used to subtract instrument noise and drift. Injections were performed in duplicate for each concentration and in a randomised order.

\section{Quantitative RT PCR}

RNA was extracted from 293T cells 5 days posttransfection, using Trizol (Invitrogen) in accordance with the manufacturer's protocol. The extracted RNA was then treated with DNase (Amplification grade, Invitrogen) and reverse transcribed. Subsequently, realtime PCR was performed using the SYBR Green QuantiTect RT-PCR Kit (Qiagen) and the Mx3000P real-time cycler in accordance with the manufacturer's instructions. Data were analysed in accordance with manufacturers' instructions.

\section{$\left[{ }^{35} \mathrm{~S}\right]$-methionine and $\left[{ }^{35} \mathrm{~S}\right]$-cysteine pulse-chase}

In $9 \cdot 5 \mathrm{~cm}^{2}$ 6-well plates, $293 \mathrm{~T}$ cells were transfected by Fugene 6 using $1 \mu \mathrm{g}$ plasmid DNA and a 6:1 plasmid:Fugene ratio in growth media (DMEM with $2 \mathrm{mM}$ glutamine, antibiotics and $10 \%$ fetal bovine serum). Transfected cells were incubated at $37^{\circ} \mathrm{C}$ in a humidified incubator supplied with $5 \% \mathrm{CO}_{2}$ for $24 \mathrm{~h}$
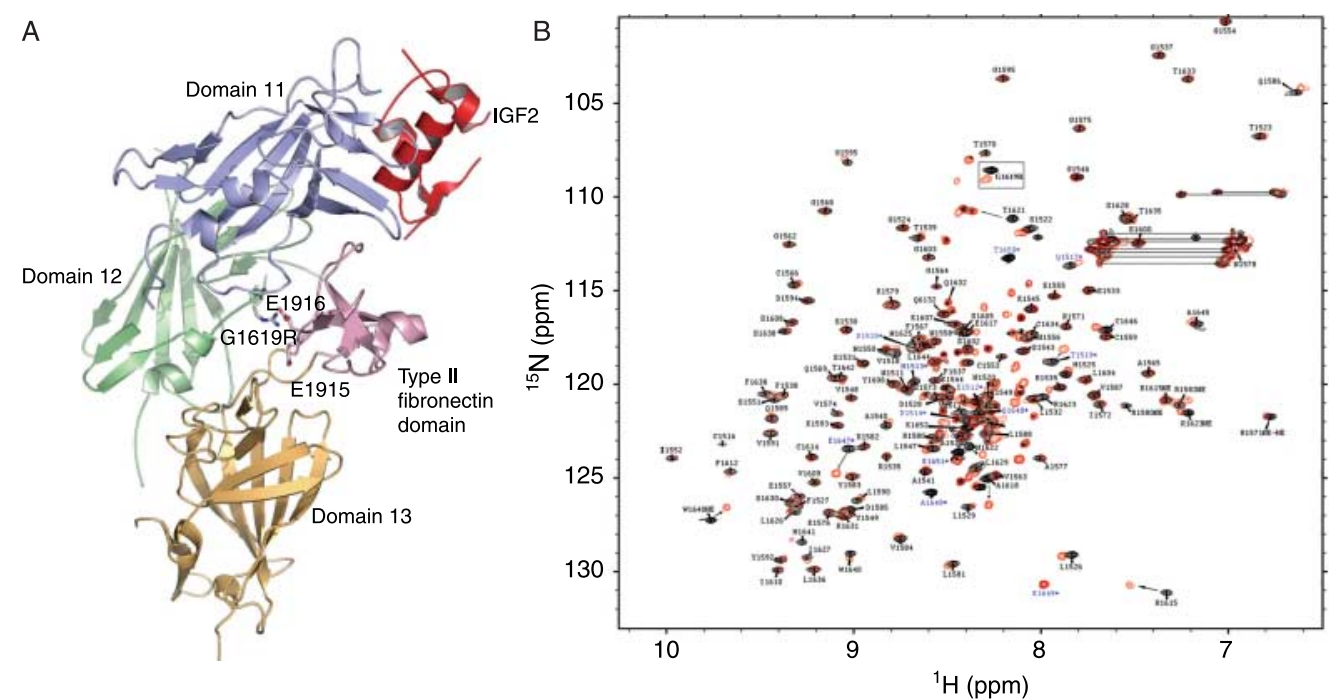

Figure 1 Structural localisation of Gly1619 of IGF2R domain 11. (A) Crystal structure of IGF2R domain 11-13 bound to IGF2(2) (PDB: 2V5P). Gly1619 is located in a long loop between $\beta$-strands $G$ and H. Modelling of the arginine replacement of glycine (Gly1619Arg) suggests that the Gly1619Arg polymorphism may interact with a group of charged residues of the fibronectin type II (FnII) domain of domain 13, rendered as pink sticks, e.g. Glu1916 and Glu1915. (B) Comparison of the ${ }^{1} \mathrm{H}-{ }^{15} \mathrm{~N}$ HSQC spectra of wild-type (Gly1619, black) and Arg1619 (red) domain 11 recorded at $600 \mathrm{MHz}$ at pH5.5, $25^{\circ} \mathrm{C}$. Side chain $\mathrm{NH}_{2}$ groups of Asn and Gln are indicated by lines parallel to the ${ }^{1} \mathrm{H}$ axis and the Gly1619Arg polymorphism is boxed. Changes in the spectra due to differences in the constructs are highlighted with an asterisk. 


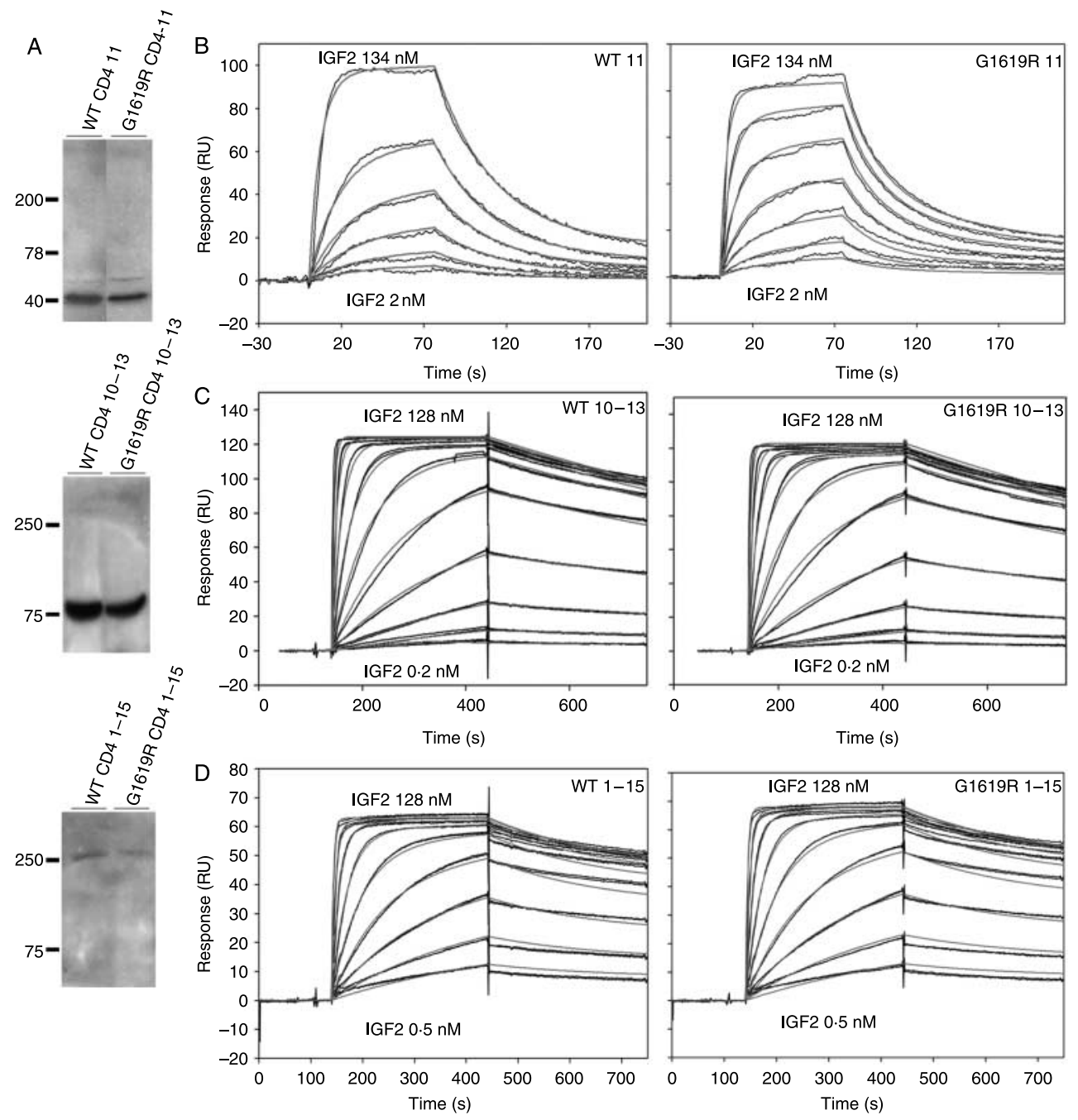

Figure 2 Protein expression and real-time kinetic analysis of wild-type and Gly1619Arg IGF2R binding to IGF2. (A) Western blot detection of the expressed and biotinylated recombinant proteins. Soluble CD4 chimeric proteins were biotinylated, subjected to SDS-PAGE and directly probed with streptavidin conjugated to alkaline phosphatase. (B) Representative sensorgrams depicting injections of recombinant IGF2 at 2, 4, 8, 16, 33 and $134 \mathrm{nM}$ binding to immobilised CD4-11 chimeric proteins; WT domain 11 (WT 11) and Gly1619Arg (abbreviated to G1619R) domain 11 (G1619R 11). (C) and (D) Representative sensorgrams depicting duplicate injections of recombinant IGF2 at $0 \cdot 2,0 \cdot 5,1,2,4,8,16,32,64,128 \mathrm{nM}$ binding to CD4-11 chimeric proteins; wild-type recombinant 10-13 domains (WT 10-13), Gly1619Arg recombinant 10-13 domains (Gly1619Arg 10-13), wild-type recombinant 1-15 domains (WT 1-15) and Gly1619Arg recombinant 1-15 domains (G1619R 1-15). Constructs and ranges of analyte concentrations are indicated. Grey lines represent the global fitting of the data set to a two-state (conformational change) binding model (see also Table 1).

prior to initiation of pulse-chase. Cells were first washed twice with PBS and incubated for 30-60 min in $1 \mathrm{ml}$ starvation medium (methionine/cysteine-free DMEM, $50 \mathrm{u} / \mathrm{ml}$ penicillin, $50 \mu \mathrm{g} / \mathrm{ml}$ streptomycin and $2 \mathrm{mM}$ glutamine). For metabolic labelling, the starvation medium was replaced with $500 \mu \mathrm{l} /$ well of pulse medium (starvation medium $+0 \cdot 1 \mathrm{mCi} / \mathrm{ml}\left[{ }^{35} \mathrm{~S}\right]$-methionine and $\left[{ }^{35} \mathrm{~S}\right]$-cysteine Redivue Pro-Mix) and pulsed for $1 \mathrm{~h}$ or $12 \mathrm{~h}$ at $37^{\circ} \mathrm{C}$ and $5 \% \mathrm{CO}_{2}$. Metabolic labelling was stopped by adding $500 \mu \mathrm{l}$ per well of chase medium (starvation medium supplemented with cold $5 \mathrm{mM}$ cysteine and $5 \mathrm{mM}$ methionine), washed and incubated $1 \mathrm{ml}$ per well of chase medium. After the selected chase time, supernatants were recovered, centrifuged at $5000 \mathrm{~g}$ for $5 \mathrm{~min}$, immediately snap-frozen in liquid nitrogen and stored at $-80^{\circ} \mathrm{C}$ until all chase samples were collected. For each selected chase time, cells were incubated for $30 \mathrm{~min}$ on ice $\left(4^{\circ} \mathrm{C}\right)$ in $500 \mu \mathrm{l} /$ well lysis 
Table 1 BIAcore kinetic analysis of IGF2 and latent TGF $\beta 1$ binding to recombinant IGF2R chimeric domains

\begin{tabular}{|c|c|c|c|c|c|c|c|c|c|}
\hline & $\begin{array}{l}\text { Immobilised ligand } \\
\text { on SA sensor chip }\end{array}$ & $\begin{array}{l}\boldsymbol{k}_{\mathrm{a} 1}(1 / \mathrm{Ms}) \\
\left(\times 10^{5}\right)\end{array}$ & $\begin{array}{l}\boldsymbol{k}_{\mathrm{d} 1}(1 / \mathrm{s}) \\
\left(\times 10^{-2}\right)\end{array}$ & $\begin{array}{l}\boldsymbol{k}_{\mathrm{a} 2}(1 / \mathrm{Ms}) \\
\left(\times 10^{-3}\right)\end{array}$ & $\begin{array}{l}\boldsymbol{k}_{\mathrm{d} 2}(1 / \mathrm{s}) \\
\left(\times 10^{-3}\right)\end{array}$ & $\begin{array}{l}K_{\mathbf{D}}(\mathrm{M}) \\
\left(\times 10^{-9}\right)\end{array}$ & $\begin{array}{l}\text { Relative } \\
K_{\mathrm{D}}\end{array}$ & $x^{2}$ & $\begin{array}{l}\text { Steady state } \\
K_{\mathrm{D}}(\mathrm{M}) \\
\left(\times 10^{-9}\right)\end{array}$ \\
\hline \multirow[t]{3}{*}{$\begin{array}{l}\text { Analyte } \\
\text { IGF2 }\end{array}$} & $\begin{array}{l}\text { CD4 IGF2R-Dom11 } \\
\text { WT } \\
\text { Gly }{ }^{1619} \text { Arg }\end{array}$ & $\begin{array}{l}8 \cdot 65 \\
7 \cdot 03\end{array}$ & $\begin{array}{l}2 \cdot 68 \\
2 \cdot 44\end{array}$ & $\begin{array}{l}2 \cdot 01 \\
1 \cdot 27\end{array}$ & $\begin{array}{l}1 \cdot 37 \\
2 \cdot 05\end{array}$ & $\begin{array}{l}31 \cdot 2 \\
34 \cdot 7\end{array}$ & $\begin{array}{l}1 \\
1 \cdot 11\end{array}$ & $\begin{array}{l}2 \cdot 1 \\
3 \cdot 2\end{array}$ & $\begin{array}{l}36 \cdot 5 \\
36 \cdot 3\end{array}$ \\
\hline & $\begin{array}{l}\text { CD4 IGF2R-Dom10-13 } \\
\text { WT } \\
\text { Gly }{ }^{1619} \text { Arg }\end{array}$ & $\begin{array}{l}1.23 \pm 0.14 \\
1.21 \pm 0.12\end{array}$ & $\begin{array}{l}1.72 \pm 0.5 \\
1.68 \pm 0.43\end{array}$ & $\begin{array}{l}3 \cdot 51 \pm 2 \cdot 19 \\
3 \cdot 85 \pm 2 \cdot 82\end{array}$ & $\begin{array}{l}2 \cdot 15 \pm 0 \cdot 82 \\
4 \cdot 14 \pm 1 \cdot 36\end{array}$ & $\begin{array}{l}1.35 \pm 0.27 \\
1.37 \pm 0.26\end{array}$ & $\begin{array}{l}1 \\
1 \cdot 01\end{array}$ & $\begin{array}{l}11 \cdot 1 \\
11 \cdot 2\end{array}$ & $\begin{array}{l}2 \cdot 76 \pm 0.31 \\
2 \cdot 83 \pm 0.31\end{array}$ \\
\hline & $\begin{array}{l}\text { CD4 IGF2R-Dom1-15 } \\
\text { WT } \\
\text { Gly }{ }^{1619} \mathrm{Arg}\end{array}$ & $\begin{array}{l}1 \cdot 75 \pm 0 \cdot 19 \\
1 \cdot 67 \pm 0 \cdot 16\end{array}$ & $\begin{array}{l}2 \cdot 15 \pm 0 \cdot 13 \\
2 \cdot 09 \pm 0 \cdot 11\end{array}$ & $\begin{array}{l}2.29 \pm 0.22 \\
2.54 \pm 0.23\end{array}$ & $\begin{array}{l}4 \cdot 68 \pm 1 \cdot 79 \\
1 \cdot 86 \pm 0 \cdot 6\end{array}$ & $\begin{array}{l}1 \cdot 27 \pm 0 \cdot 2 \\
1 \cdot 29 \pm 0 \cdot 2\end{array}$ & $\begin{array}{l}1 \\
1 \cdot 01\end{array}$ & $\begin{array}{l}1.6 \\
0.9\end{array}$ & $\begin{array}{l}1.99 \pm 0.3 \\
2 \cdot 09 \pm 0.3\end{array}$ \\
\hline \multirow{2}{*}{$\begin{array}{l}\text { Latent } \\
\text { TGF } \beta 1\end{array}$} & CD4 IGF2R-Dom1-15 & & & & & & & & \\
\hline & $\begin{array}{l}\text { WT } \\
\text { Gly }{ }^{1619} \text { Arg }\end{array}$ & $\begin{array}{l}3 \cdot 33 \\
2 \cdot 99\end{array}$ & $\begin{array}{l}0.61 \\
0.58\end{array}$ & $\begin{array}{l}1 \cdot 93 \\
1 \cdot 9\end{array}$ & $\begin{array}{l}0.0016 \\
0.0033\end{array}$ & $\begin{array}{l}18 \cdot 3 \\
19 \cdot 4\end{array}$ & $\begin{array}{l}1 \\
1 \cdot 06\end{array}$ & $\begin{array}{l}2 \cdot 4 \\
2 \cdot 5\end{array}$ & $\begin{array}{l}1 \\
1\end{array}$ \\
\hline
\end{tabular}

buffer (50 mM Tris-HCL pH 7.4, $150 \mathrm{mM} \mathrm{NaCl,} 2 \mathrm{mM}$ $\mathrm{MgCl}_{2}, 1: 1000$ protease inhibitor cocktail (Sigma P3840), 1:1000 PMSF from a $200 \mathrm{mM}$ Stock in Isopropanol). Cell lysates were then snap frozen in liquid nitrogen and stored at $-80^{\circ} \mathrm{C}$. For immunoprecipitation (IP), liquid scintillation counting and protein assays, unfrozen samples were centrifuged at $10600 \mathrm{~g}$ for $10 \mathrm{~min}$ to pellet the nuclei and remove debris. Immuno-precipitation was performed using $20 \mu \mathrm{l}$ Protein G-Sepharose $(2 \mathrm{mg} / \mathrm{ml})$ beads for each sample, where PBS-washed beads and $1 \mu \mathrm{l}$ antibody were incubated with slow rotation overnight at $4{ }^{\circ} \mathrm{C}$ with either $250 \mu \mathrm{l}$ of the recovered supernatants or $50 \mu \mathrm{l}$ cell lysates in a total volume $600 \mu \mathrm{l}$. Pellets were then washed three times with PBS and prepared for SDS-PAGE analysis by final re-suspension in $15 \mu \mathrm{l} /$ pellet of $5 \times$ Sample buffer $(200 \mathrm{mM}$ Tris-HCl pH 6.8, 10\% SDS, $50 \%$ glycerol, $5 \%$ 2-mercaptoethanol, $0.05 \%$ bromophenol blue) and $5 \mathrm{~min}$ boiling at $95{ }^{\circ} \mathrm{C}$. Immuno-precipitation products were loaded in $5 \%$ $(\mathrm{w} / \mathrm{v})$ polyacrylamide gels and were run at $200 \mathrm{~V}$ for $35 \mathrm{~min}$, dried on $0.5 \mathrm{~mm}$ Whatman filter paper in a vacuum-heated gel dryer and exposed to a BioRad phosphor imaging screen.

Scanning densitometry was used to quantify radioactivity, and values were expressed relative to a loading control of total radioactivity in each sample. The latter was determined by total liquid scintillation counting using PerkinElmer scintillation cocktail (Ultima Gold LLT).

\section{Flow cytometry}

Cells were detached from plates using $0 \cdot 1 \mathrm{mM}$ EDTA. For cell surface detection with an intact cell membrane, cells were not fixed or permeablised, however, for total expression, cells were fixed in $1 \mathrm{ml}$ paraformaldehyde $\left(2 \% \mathrm{w} / \mathrm{v}\right.$ in PBS, pH 7.4) at $4{ }^{\circ} \mathrm{C}$ for $30 \mathrm{~min}$ and permeablised in $0.1 \% \mathrm{v} / \mathrm{v}$ Triton in $2 \% \mathrm{w} / \mathrm{v}$ paraformaldehyde at $4{ }^{\circ} \mathrm{C}$ for $30 \mathrm{~min}$.

Cells were treated with $1 \mathrm{ml}$ buffer (1\% BSA in PBS) and stained using $100 \mu \mathrm{l}$ buffer with 1:50 diluted primary antibody (AbD Serotec mouse anti-human IGF2R CD222) and incubated at room temperature for $1 \mathrm{~h}$ at $4^{\circ} \mathrm{C}$. Cells were than washed and incubated in $100 \mu \mathrm{l}$ buffer with 1:50 diluted secondary antibody (Caltag goat anti-mouse PE/Cy5) for $1 \mathrm{~h}$ at $4{ }^{\circ} \mathrm{C}$. Cells were analysed using a Becton Dickinson FACSCalibur system and data were analysed using WinMDI 2.8 software.

\section{Single nucleotide polymorphism bioinformatics analyses}

The allele frequency of rs629849 and linkage disequilbrium of IGF2R around this SNP was investigated using publicly available genotype data from the HapMap (Han Chinese, Japanese, and Yoruba) (Frazer et al. 2007), SNP500Cancer (African/African American, Caucasian, Hispanic, and Pacific Rim) (Packer et al. 2006) and the Multi-Ethnic Cohort (Black, Hawaiian, Japanese, Latino, and White) (Kolonel et al. 2004). Haploview (version 4.1) was used to calculate measures of linkage disequilibrium (LD). These measures included absolute $\mathrm{D}^{\prime}$ (a measure of the covariance of allele counts for two SNPs under the assumption of Hardy-Weinberg equilibrium), the $95 \%$ confidence intervals for $\mathrm{D}^{\prime}$, LOD scores (log of the likelihood ratio, a measure of the confidence in the value of $\mathrm{D}^{\prime}$ ), and the 

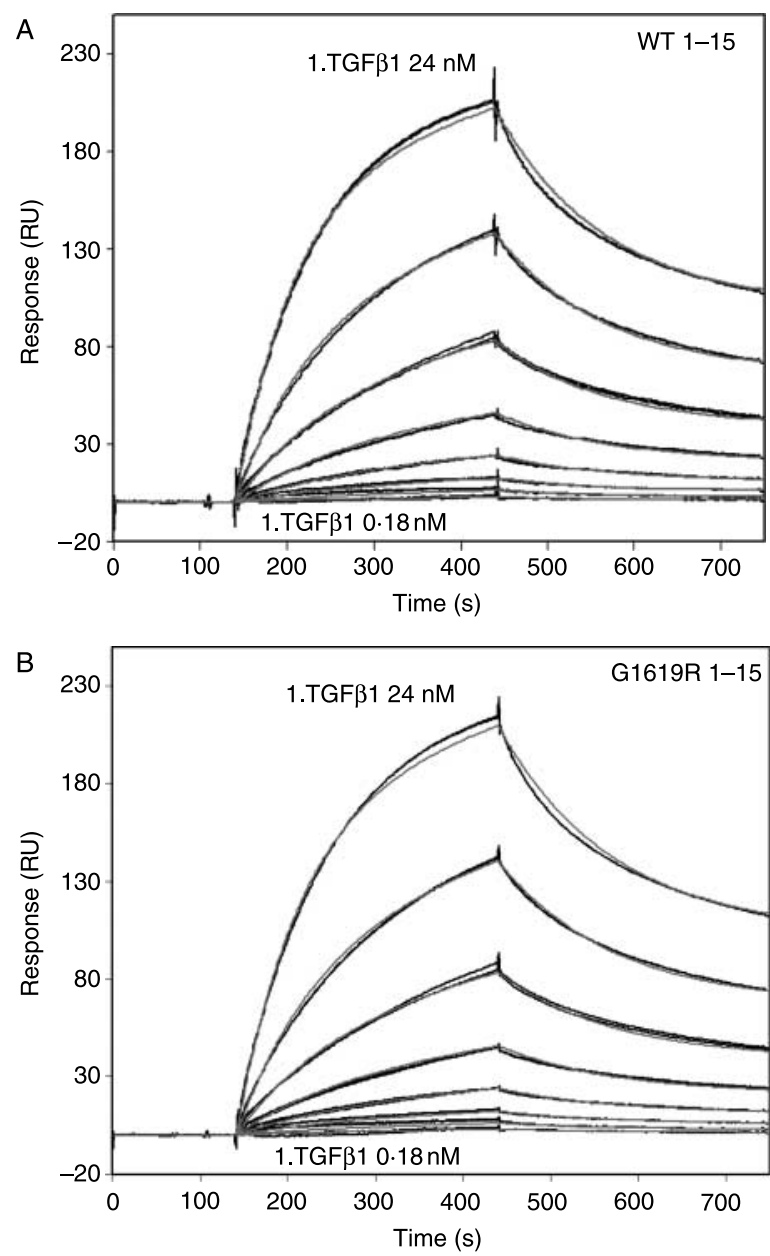

Figure 3 Real-time kinetic evaluation of the binding of latentTGF $\beta 1$ to wild-type and G1619R IGF2R domains $1-15$. Representative sensorgrams depicting duplicate injections of recombinant latent TGF $\beta 1$ at $0.18,0.37,0.75,1.5,3,6,12$ and $24 \mathrm{nM}$ binding to immobilised CD4-11 chimeric proteins; wild-type recombinant 1-15 domains (WT 1-15) (A) and Gly1619Arg recombinant 1-15 domains (G1619R 1-15) (B). Constructs and ranges of analyte concentrations are indicated. Grey lines represent the global fitting of the data using a two-state (conformational change) binding model (see also Table 1).

$R$-squared $\left(R^{2}\right)$ statistic (correlation coefficient for the pairwise comparison of the SNPs) (Barrett et al. 2005).

\section{Results}

\section{Structural location, conformation and modelling of Gly1619Arg}

We first determined the localisation of Gly1619 in relation to the IGF2 binding site of human IGF2R domain 11. We utilised our high resolution NMR and X-ray crystallographic structures of human IGF2 bound to $11-13$ of IGF2R at $4 \cdot 1 \AA$ (Williams et al. 2007, Brown et al. 2008). Both the solution structure of domain 11 of IGF2R, and the modelled IGF2 binding interaction using HADDOCK, located Gly1619 in the GH loop region, distant from the cluster of differentiation, $\mathrm{AB}$ and FG that formed the IGF2 binding site (Fig. 1A) (Williams et al. 2007, Brown et al. 2008). IGF2 induced conformational changes in domain 11 structure detected by NMR were predominantly located in the binding loops $(\mathrm{AB}$, cluster of differentiation and $\mathrm{FG}$ loops) rather than the carbon backbone of the $\beta$-barrel structure.

Detailed examination of domain $11{ }^{1} \mathrm{H}^{15} \mathrm{~N}$ heteronuclear single quantum coherence (HSQC) spectra showed that Arg1619 modification did not significantly alter protein conformation when compared with Gly1619 (Fig. 1B). Moreover, comparison of the crystal structures of ligand free domains of $11-14$ at $2.9 \AA$, and domains $11-13$ with IGF2 bound at $4 \cdot 1 \AA$, also showed no conformational change in either the localisation or juxtaposition of G1619 (see Supplementary Figure S3 of Brown et al. (2008)). Modelling of the arginine replacement of glycine revealed a number of new potential electrostatic interactions with Glu1916 and Glu1915 of the fibronectin type II (FnII) domain of domain 13 (Fig. 1A). These new interactions may help to stabilise the fibronectin type II domain, and alter the orientation of the interaction with the $\mathrm{AB}$ loop of domain 11 that can modify IGF2 binding (Brown et al. 2008). The FnII residues interacting with the AB loop are on the same long loop as those that could possibly interact with Gly/Arg1619, namely Ser1921 and Arg1922, and possibly Trp1639. As a result of the location of Gly1619 between domain 11 and 12, it is also possible that Arg1619 may alter the conformation between domains on ligand binding of IGF2, which may not only alter IGF2 interactions with domain 11, but may also alter the subsequent binding of mannose 6-phosphate to domain 3, 5 and 9.

\section{Real-time analysis of IGF2 ligand binding using SPR}

Analysis of the domain 11 structure suggested that the Gly1619Arg polymorphism may alter the IGF2 binding interaction indirectly by modifying the interaction between the $A B$ loop of IGF2R domain 11 and the FnII domain of domain 13 . We had previously mutated the $\mathrm{AB}$ loop residues and identified Glu1544 as an important residue in the interaction with IGF2, and when mutated to a Lys a sixfold enhanced affinity to IGF2 was observed (Zaccheo et al. 2006). Moreover, when we deleted the FnII domain in domain 13, we detected an increased 'off rate' of the interaction by tenfold with IGF2, which could be partially rescued by the Glu1544Lys mutation (Brown et al. 2008). By utilising protein expression systems we have previously 

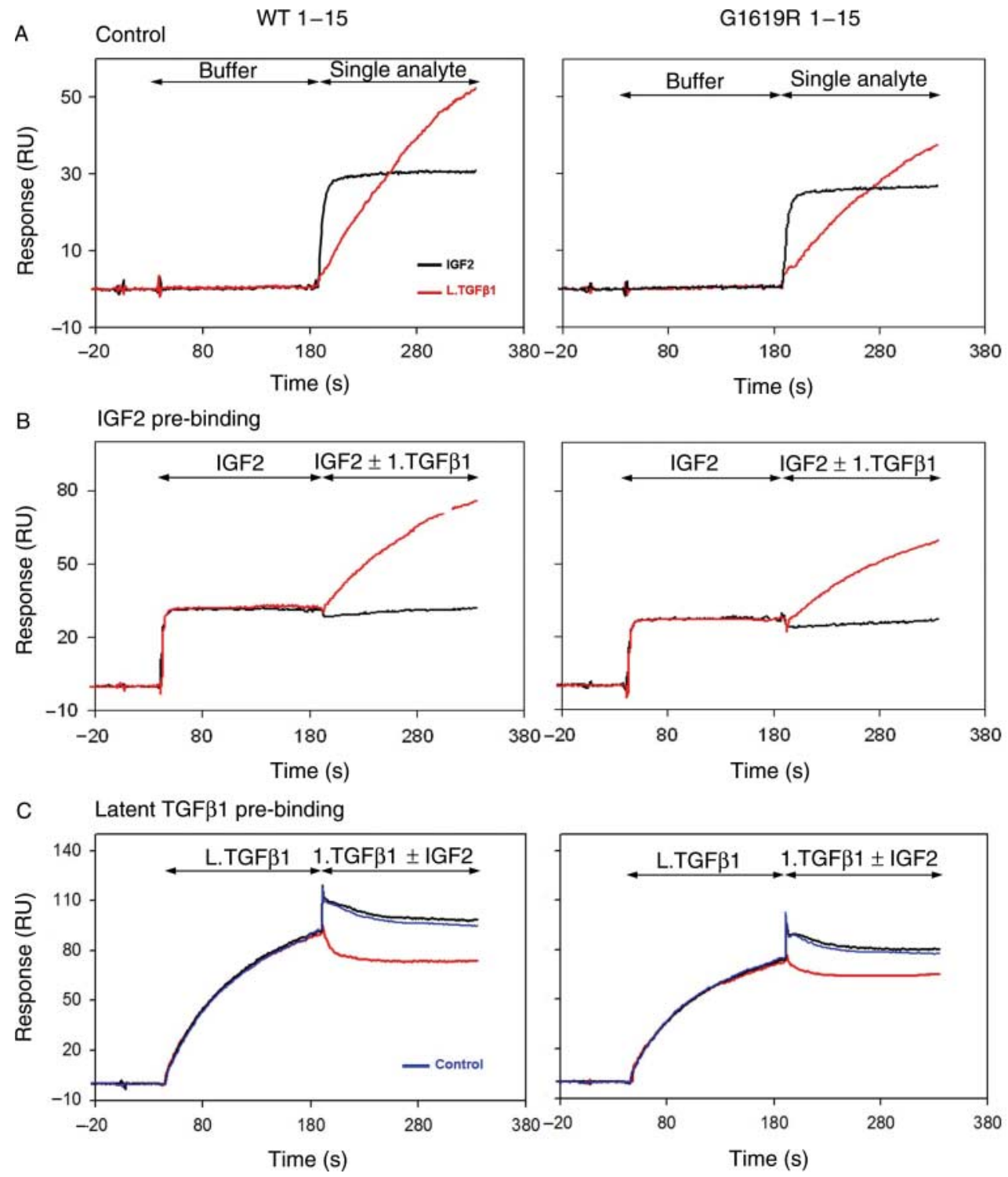

Figure 4 Real-time kinetic evaluation of IGF2 and latent-TGF $\beta 1$ competition binding to CD4-chimeric wild-type and G1619R IGF2R domains 1-15. (A) Representative sensorgrams of control $100 \mu$ injections of HBS-EP buffer followed by $100 \mu$ of HBS-EP buffer containing a single analyte, with subsequent binding to immobilised recombinant CD4-chimeric Gly1619 1-15 domains (WT, 1-15) and Arg1619 1-15 domains (G1619R 1-15). 130 nM IGF2 in buffer (black lines), $30 \mathrm{nM}$ latent-TGF $\beta 1$ in buffer (red lines) are shown together. (B) The effect of IGF2 pre-binding on the subsequent latent-TGF $\beta 1$ binding to WT 1-15 and Gly1619Arg 1-15. Representative sensorgrams are shown. Initial injections of IGF2 (130 nM) alone were followed either by injection of the same concentration of IGF2 (130 nM) in buffer (black lines) or $130 \mathrm{nM}$ IGF2 with $30 \mathrm{nM}$ latent-TGF $\beta 1$ (red lines). Similar latent-TGF $\beta 1$ binding profiles were observed. (C) The effect of latent-TGF $\beta 1$ prebinding on the subsequent IGF2 binding to WT 1-15 and Gly1619 Arg 1-15. Injections of latent-TGF $\beta 1$ (30 nM) were either followed by injection of $30 \mathrm{nM}$ latent-TGF $\beta 1$ in buffer (red lines), $30 \mathrm{nM}$ latent-TGF $\beta 1$ plus $130 \mathrm{nM}$ IGF2 (black lines) or $130 \mathrm{nM}$ IGF2 only as control (blue lines). The expected binding profile of IGF2 was not detected, and the extent of inhibition was similar in Gly1619 and Arg1619.

described, we mutated Gly1619 to Arg using site directed mutagenesis, and expressed both soluble Histagged IGF2R domain 11 using Pichia pastoris, and chimeric soluble rat CD4 tagged IGF2R domains 11, 10-13 and 1-15 using 293T cells (Linnell et al. 2001, Zaccheo et al. 2006). Proteins were expressed and single bands identified on western blots (Fig. 2A). Proteins were biotinylated and immoblised on BIAcore biosensor chips and recombinant IGF2 ligand was passed over the sensor surface at increasing concentration and at high flow-rates $(40 \mu \mathrm{l} / \mathrm{min})$. The resulting sensograms were fitted using a two-state conformational 


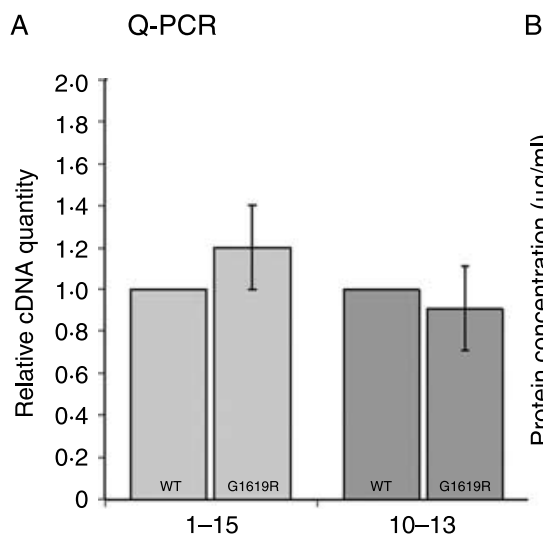

B CD4 ELISA

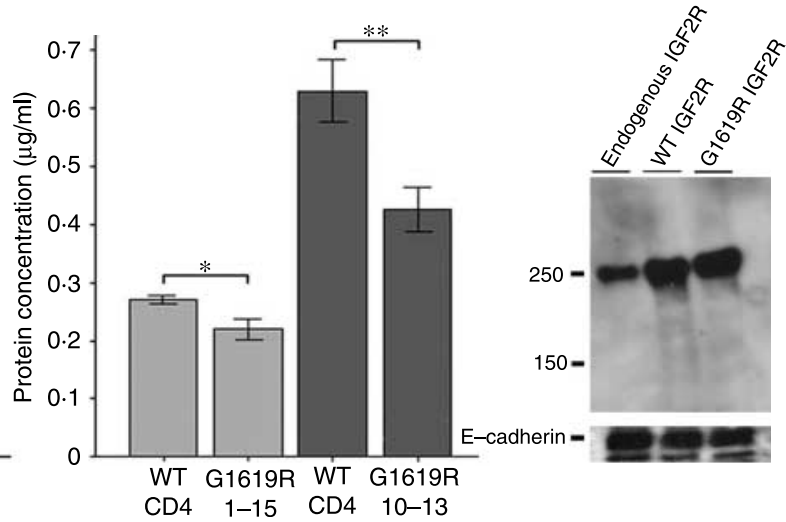

Figure 5 Quantification of mRNA and protein levels in 293T cells transfected with wild-type (WT) and Gly1619Arg IGF2R CD4-1-15. (A) Relative expression of CD4-IGF2R Gly1619Arg mRNA relative to wildtype (1-15 and 10-13) using quantitative RT-PCR. Three separate single comparisons with single value WT taken arbitrarily as 1 and G1619R taken as a ratio. Values are mean \pm S.E.M. of three different experiments. Expression was normalised relative to GAPDH. The efficiency of the conducted PCR experiments, as assessed from standard curves, was between 95 and $100 \%$. (B) Quantification of expressed soluble proteins using a CD4 inhibition ELISA suggested that there was no difference in CD4-1-15 proteins but potentially reduced relative amounts of CD4-10-13 Arg1619. Mean \pm S.E.M. of six different experiments. $P$ values ${ }^{*} 0.043,{ }^{* *} 0.015$ using students $t$-test. (C) Western blot of endogenous and over-expressed wild-type and G1619R membrane bound IGF2R 1-15 (non-CD4 chimeric) in transfected 293T cell lysates. Samples were subjected to SDS-PAGE and probed with rabbit anti-human IGF2R. The blot was re-probed using rabbit antiE-cadherin loading control.

change model with BIA evalution software (examples shown in Fig. 2B-D). We had previously validated these biosensor kinetic assays and have shown them to be sensitive enough to detect subtle changes in binding kinetics with single point mutations (Zaccheo et al. 2006). Comparison of domain 11 alone, domains 10-13 and domains 1-15 with and without Gly1619Arg showed no significant difference in association and dissociation kinetics (Table 1). Moreover, when biotinylated IGF2 was immobilised, the binding profiles of soluble receptor constructs showed mass transport effects but no differences between Gly1619 and Arg1619, suggesting that differences were not masked by any tethering effect of immobilised receptors (not shown). Thus, we could not detect any difference in affinity between Gly1619 and Arg1619 using single and multiple domain recombinant proteins and SPR.

\section{Real-time analysis of mannose 6-phosphate ligand binding using SPR}

We next tested the effects of the Gly1619Arg mutant domain 1-15 proteins on binding to mannose 6-phosphate. For this reaction, we utilised mannosylated latent-TGF $\beta 1$ that we had previously tested (Linnell et al. 2001, Zaccheo et al. 2006). Concentration dependent binding sensorgrams were fitted using a global model (expected stoichiometry of 2:1, Fig. 3 representative sensorgrams) and association and dissociation rates calculated (Table 1). Again, we could not detect significant differences in binding to latentTGF $\beta 1$ alone. Previous reports suggested that binding of IGF2 and latent-TGF $\beta 1$ to IGF2R may be mutually exclusive (Kiess et al 1989, 1990). In order to test the hypothesis that Gly1619Arg mutation might have altered these interactions, we designed an experiment where either IGF2 or latent-TGF $\beta 1$ was pre-bound to immobilised biotinylated CD4-1-15 on a streptavidin biosensor chip (Fig. 4). Kinetics of binding to single analyte was first compared (Fig. 4A), before IGF2 was pre-bound at $130 \mathrm{nM}$ (saturation concentration), followed by latent-TGF $\beta 1(30 \mathrm{nM})$ combined with IGF2 (130 nM; Fig. 4B). Examination of sensorgrams revealed similar binding of latent-TGF $\beta 1$ irrespective of whether IGF2 was pre-bound (Fig. 4B). However, when latent-TGF $\beta 1$ was loaded on the sensor chip prior to IGF2, the subsequent binding of IGF2 was significantly impaired when co-injected with latent-TGF $\beta 1$ or alone as a control, indicating that occupied mannose 6-phosphate binding sites impaired IGF2 binding. There were no significant differences in binding kinetics detected between Gly1619 (wild-type) and Arg1619 (Fig. 4C). Thus, we confirmed previous reports that mannose 6-phosphate binding may compete with the IGF2 interaction, an effect presumed to be due to steric hindrance, although indirect conformational changes in binding loops of domains 3 and 9 have not been excluded (Kiess et al. 1989, 1990). 
A CD4-1-15 IGF2R pulse-chase (1 $\mathrm{h}$ pulse)

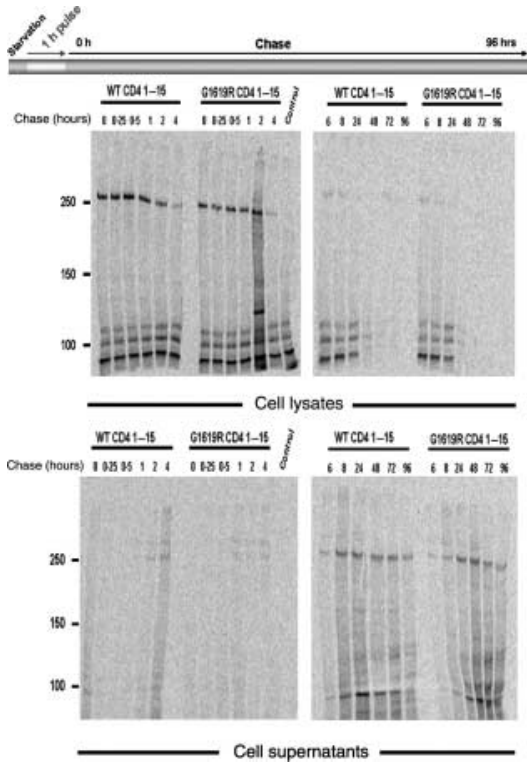

C 1-15 IGF2R pulse-chase (1 $\mathrm{h}$ pulse)

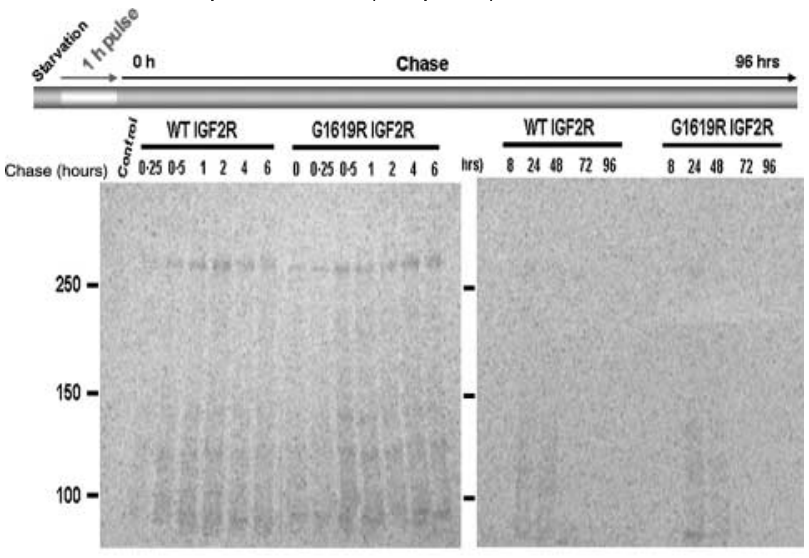

Cell lysates

E 1-15 IGF2R pulse-chase (12 h pulse)

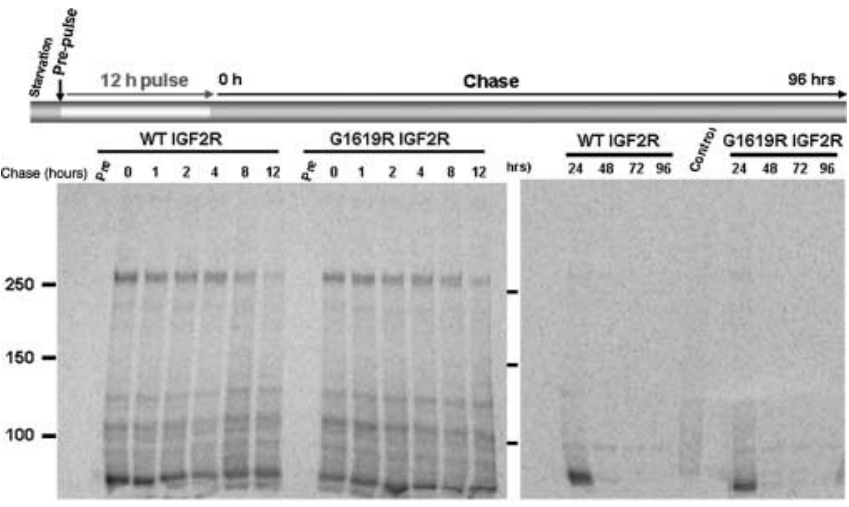

Cell lysates
B $1 \mathrm{~h}$ pulse (CD4-1-15 IGF2R)
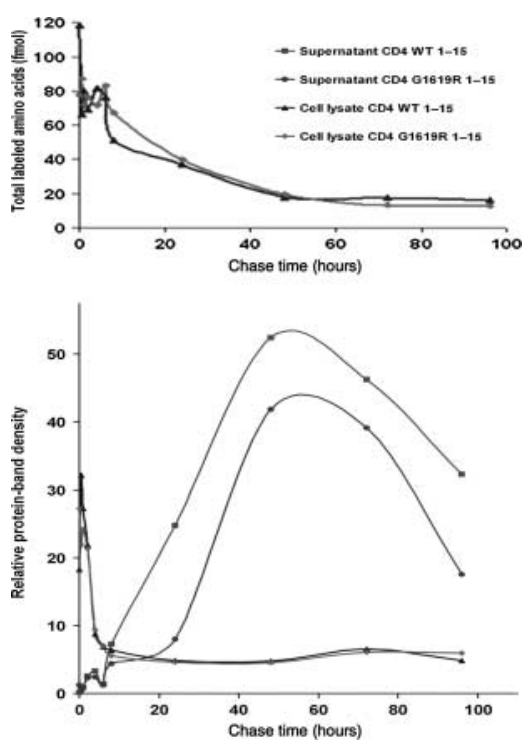

D $1 \mathrm{~h}$ pulse (1-15 IGF2R)
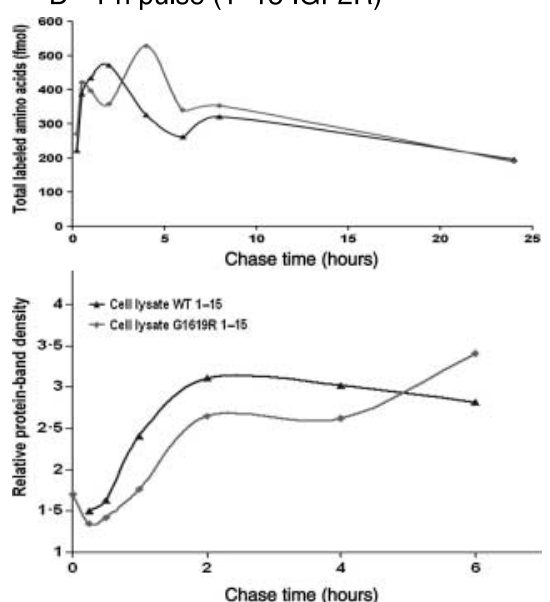

F $12 \mathrm{~h}$ pulse (1-15 IGF2R)
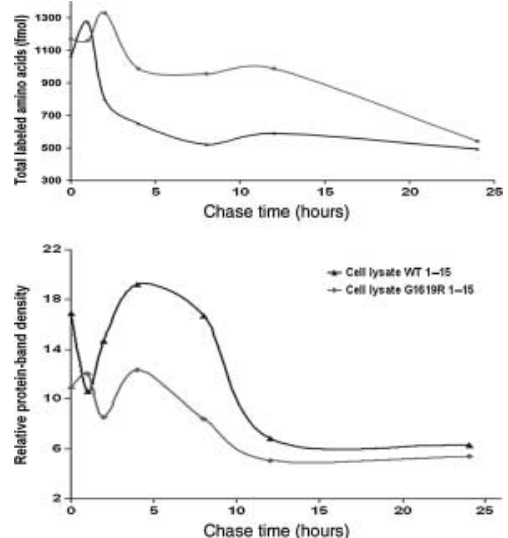


\section{Expression and half-life of IGF2R Gly1619 and Arg1619 in mammalian cells}

In order to determine whether the polymorphism altered either RNA or protein stability, we transiently over-expressed both soluble and membrane bound versions of IGF2R domains 1-15 in 293T cells. Messenger RNA expression and protein levels were quantified using quantitative RT-PCR and a previously described CD4 inhibition ELISA (for soluble CD4-1-15 proteins) respectively (Davis et al. 1990, Linnell et al. 2001). No significant changes in mRNA levels and $1-15$ protein constructs were detected (Fig. 5A and C), although a significant relative reduction in level of the CD4-10-13 Arg1619 and CD4-1-15 Arg1619 was observed. It was possible that either selective proteolysis or alteration in protein half-life accounted for these results with $\mathrm{CD} 4$ chimeric proteins, the former a mechanism of IGF2R turnover (Clairmont and Czech 1991), the latter having been described for mutations of the membrane receptors (Nakayama et al. 2004, Sharma et al. 2004).

In order to further investigate these results, we next performed ${ }^{35} \mathrm{~S}$-methionine pulse-chase experiments in 293T cells transiently transfected with CD4-1-15 Gly1619 and CD4-1-15 Arg 1619 to generate soluble proteins, and 1-15Gly1619 and 1-15Arg1619 to generate membrane bound proteins. Cell lysate and supernatant samples were immuno-precipitated with antibodies to either CD4 or IGF2R depending on whether soluble or membrane bound proteins were expressed respectively. SDS protein gels were exposed and quantified by phosphorimaging, and radioactivity expressed relative to a control of the total radioactivity in the sample. Following a $1 \mathrm{~h}$ pulse and $96 \mathrm{~h}$ chase, soluble CD4-1-15 proteins were chased into the supernatants from cell lysates with similar kinetics and levels between Gly1619 and Arg1619 (Fig. 6A and B). For membrane bound proteins, a $12 \mathrm{~h}$ pulse resulted in higher radio-labelled protein levels in cell lysates compared with a $1 \mathrm{~h}$ pulse, with no significant overall differences observed between Gly1619 and Arg1619 half-life in cell lysates and cell culture supernatants (Fig. 6C-F). We concluded that differences in protein abundance observed following transient transfection were not related to altered half-life of IGF2R proteins.

\section{Surface membrane distribution of IGF2R protein}

Finally, we utilised membrane bound 1-15 Gly1619 and Arg1619 co-expressed with eGFP reporter plasmid following transient co-transfection in order to determine whether membrane distribution of IGF2R was altered. Immuno-fluorescence of unfixed cells with a mouse antihuman IGF2R antibody did not show altered distribution with Arg1619 (not shown). Two colour flow cytometry was then utilised to quantify surface expression of IGF2R in unfixed 293T cells and total IGF2R in cells that had been fixed and permeablised (Fig. 7). Following control transfections to set thresholds of detection (not shown), eGFP positive and PE/Cy5 anti-IGF2R positive cells were quantified, and again showed no differences in abundance and membrane protein localisation between genotypes.

\section{Genetic variation around IGF2R Gly1619Arg}

The frequency of the rs624849, Exon 34-93 A>G, Gly1619Arg SNP is variable between different human populations. Using publicly available databases, population-specific genetic variation and linkage disequilibrium (LD) of Gly1619Arg was evaluated. The frequency of the A allele ranged from 0 in the HapMap Yoruba subjects to 0.25 in Pacific Rim subjects from SNP500Cancer (Table 2). This SNP was not in HardyWeinberg equilibrium in Caucasian subjects from both HapMap and SNP500Cancer.

LD was assessed between rs629849 and SNPs $20 \mathrm{~kb}$ upstream and downstream of rs629849 with minor allele frequencies greater than or equal to $0 \cdot 01$. rs629849 was not in strong LD $\left(R^{2}>0 \cdot 8\right)$ with any SNPs in these regions. SNPs with $R^{2}$ values greater than $0 \cdot 3$ and $\mathrm{D}^{\prime}$ values $>0 \cdot 8$, suggestive, but not strongly

\footnotetext{
Figure 6 IGF2R $\left[{ }^{35} \mathrm{~S}\right.$ ] radiolabelled pulse-chase in transfected 293T cells. (A and B) Soluble CD4-IGF2R chimeric proteins. Pulse-chase analysis of IGF2R wild-type and Gly1619Arg CD4-1-15 processing by 293 T cells transiently transfected and pulsed for $1 \mathrm{~h}$ with $\left.{ }^{35} \mathrm{~S}\right]-$ cysteine and $\left[{ }^{35} \mathrm{~S}\right]$-methionine, and chased in cold media as described in methods. Supernatants and cell lysates were collected at chase time points as indicated, immuno-precipitated using mouse anti-rat CD4 antibody, and subjected to SDS-PAGE. Controls were either cell lysates or supernatants of non-transfected 293T cells. Densitometry data (B) were obtained from phosphor-imager scanned protein bands (times as indicated) and measured using ImageQuant software and normalised against total $\left[{ }^{35} \mathrm{~S}\right]$ liquid scintillation per chase sample (A). (B) Upper curves depict the total $\left[{ }^{35} \mathrm{~S}\right.$ ] liquid scintillation counts of $50 \mu \mathrm{l}$ samples of corresponding cell lysates. (C-F) Membrane bound non-CD4 IGF2R. Pulse-chase analysis of wild-type and Gly1619Arg membrane bound 1-15 IGF2R (non-CD4 chimeric) processing by 293T cells. Transiently transfected 293T cells that expressed wild-type or Gly1619Arg 1-15 IGF2R were pulsed for $1 \mathrm{~h}(\mathrm{C}$ and $\mathrm{D})$ or $12 \mathrm{~h}(\mathrm{E}$ and $\mathrm{F})$ with $\left[{ }^{35} \mathrm{~S}\right]$-cysteine and $\left[{ }^{35} \mathrm{~S}\right]$-methionine, then chased in cold media. Cell lysates were collected at various chase time points (as indicated) and immuno-precipitated using mouse anti-human IGF2R antibody, and then subjected to SDSPAGE to detect 1-15 IGF2R. Controls are cell lysates of non-transfected 293T cells and pre-pulse samples (Pre) were taken prior to metabolic labelling. Again, example phosphor-images (C and E) were quantified using ImageQuant software and normalised against total $\left[{ }^{35} \mathrm{~S}\right]$ liquid scintillation per chase sample. (D) and $(\mathrm{F})$ The upper curves depict the total $\left[{ }^{35} \mathrm{~S}\right]$ liquid scintillation counting of $50 \mu \mathrm{l}$ cell lysates and the lower curves depict the relative band intensity.
} 
A Total labelling

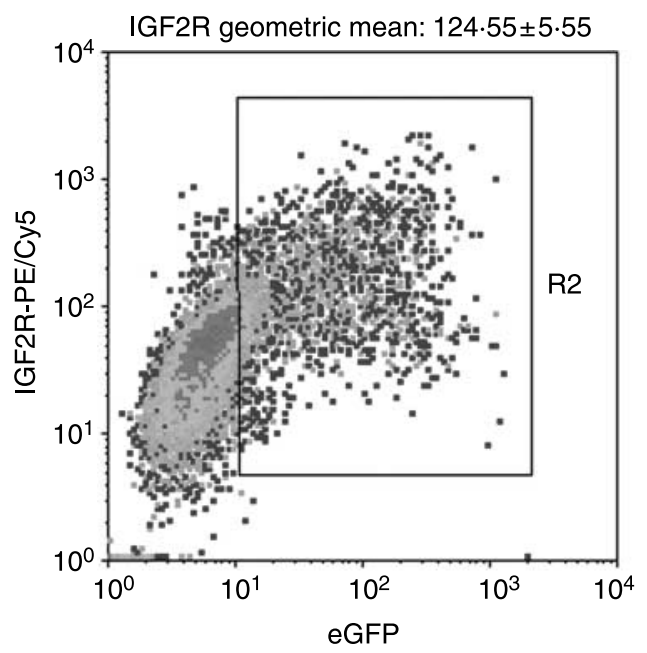

B Surface labelling

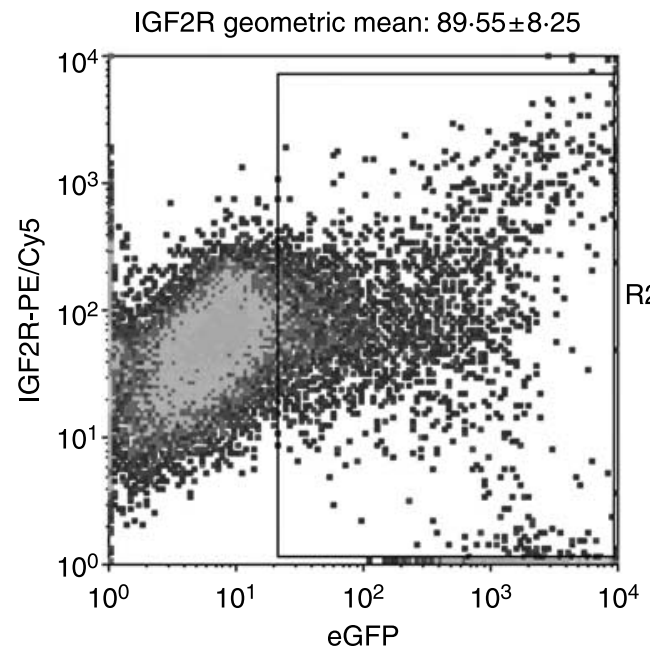

G1619R 1-15
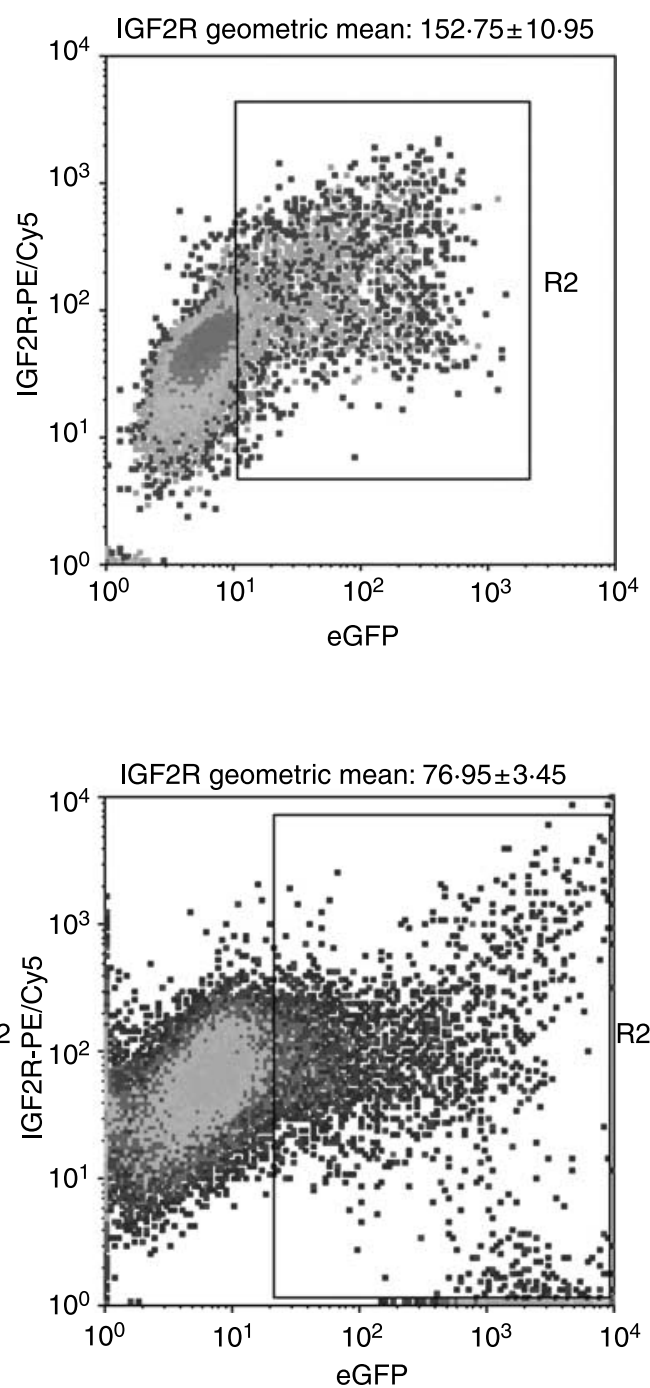

Figure 7 Flow cytometry of anti-IGF2R labelled 293T cells over-expressing membrane bound IGF2R domains 1-15. 293T cells were co-transfected with membrane bound (non-CD4 chimeric) IGF2R 1-15 (pcDNA IGF2R) and eGFP (pEGFP-N1) plasmids as described in methods. Forty-eight h post-transfection, cells were either fixed with paraformaldehyde $(2 \% \mathrm{w} / \mathrm{v})$ or permeablised with Triton $\mathrm{X} 100(0.1 \% \mathrm{v} / \mathrm{v})(\mathrm{A})$ or fixed with $4 \%(w / v)$ paraformaldehyde alone (B). Cells were incubated with mouse anti-human IGF2R, detected using PE/Cy5 secondary antibody (goat anti-mouse), co-labelling data collected with a FACSCalibur flow cytometer with minimal compensation, and then analysed using WinMDI 2.8 software. Non-transfected and secondary antibody controls were used to set background thresholds (not shown) Geometric means of staining are expressed \pm S.E.M. $(n=5)$.

supportive of LD, were noted in subjects of Asian descent from HapMap and SNP500 (Table 3). These SNPs were in nearby introns.

\section{Discussion}

Disruption of the function of IGF2R has potent consequences for IGF2 dependent overgrowth of the mammalian embryo (Wang et al. 1994, Ludwig et al. 1996, Wylie et al. 2003). Frequent mutation and loss of function of IGF2R in human tumours have also implicated the selective growth advantage of cells lacking IGF2R (De Souza et al. 1995, Hankins et al. 1996, Byrd et al. 1999, Kong et al. 2000). Of the ligands that bind IGF2R, IGF2 appeared to be the most potent in terms of gross effects on growth control. As IGF2 binds IGF2R at a selective binding site in domain 11, 
Table 2 Genetic variation of rs629849 (Ex34-93 A > G, Gly1619Arg) amongst populations

\begin{tabular}{|c|c|c|c|}
\hline & Population & $\begin{array}{l}\text { Number of } \\
\text { individuals }\end{array}$ & $\begin{array}{l}\text { A allele } \\
\text { frequency }\end{array}$ \\
\hline \multirow[t]{3}{*}{ HapMap $^{a}$} & Han Chinese & 42 & 0.143 \\
\hline & Japanese & 43 & 0.174 \\
\hline & Yoruba & 60 & 0 \\
\hline \multirow[t]{4}{*}{$\begin{array}{l}\text { SNP500Can- } \\
\text { cer }\end{array}$} & $\begin{array}{l}\text { African/African } \\
\text { American }\end{array}$ & 24 & 0.021 \\
\hline & Caucasian $^{\mathrm{b}}$ & 31 & 0.194 \\
\hline & Hispanic & 23 & $0 \cdot 130$ \\
\hline & Pacific Rim & 24 & 0.250 \\
\hline \multirow{5}{*}{$\begin{array}{l}\text { Multi-ethnic } \\
\text { Cohort }\end{array}$} & Black & 69 & 0.029 \\
\hline & Hawaiian & 69 & 0.094 \\
\hline & Japanese & 68 & 0.114 \\
\hline & Latino & 69 & 0.066 \\
\hline & White & 68 & $0 \cdot 103$ \\
\hline
\end{tabular}

${ }^{a}$ Data from CEPH Caucasians were not available from HapMap.

${ }^{\mathrm{b}}$ rs629849 was not in Hardy-Weinberg equilibrium in this group.

and with high affinity, any non-synonymous polymorphisms of this domain remain strong candidate modifiers of human embryonic and tumour growth.

A number of observational approaches have been taken to assess the functional significance of the 1619 position of domain 11 of IGF2R. During evolution of IGF2R, the receptor acquired an IGF2 ligand binding function that was associated with a number of amino acid mutations of the domain 11 binding site, yet Gly1619 appeared to be a highly conserved amino acid during the evolution of birds (chicken) to mammals (Clairmont and Czech 1989, Yandell et al. 1999, Brown et al. 2002, 2008). This evolutionary observation suggested that the non-synonymous SNP at 1619 would be unlikely to be involved in a direct interaction with IGF2. Our structural studies have also supported this notion, as the 1619 residue was remotely located with respect to the IGF2 binding site. In addition, IGF2 induced conformational changes in the binding site loop residues but not the 1619 residue, and suggested that any effect on IGF2 binding was likely to be indirect. Modelling of Arg1619 supported potential indirect effects on the FnII domain that subsequently may have lead to alteration of binding site interactions through the AB loop (Zaccheo et al. 2006). These observations led us to directly mutate Gly1619 to $\operatorname{Arg} 1619$ and to compare receptor function.

A report had correlated slower human childhood growth rate in the rare IGF2R Arg1619 (A/A) homozygotes, yet our data suggested that this amino acid change alone was non-functional in terms of IGF2 and mannose 6-phosphate ligand binding, protein half-life and cell membrane distribution (Petry et al. 2005). It is important to state that the implications of our experiments do not alter the interpretation of the

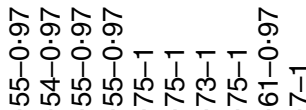
ón 
positive correlation between circulating concentrations of IGF2, and inverse correlation with soluble IGF2R and human growth (Ong et al. 2000, Garrone et al. 2002). However, our data make it difficult to directly attribute the phenotypic growth effects with Gy1619Arg to IGF2R receptor function. Even though the observations of Petry et al. (2005) are unconfirmed, our observations do not alter the $\operatorname{Arg} 1619$ correlation observed (Kaku et al. 2007), as there are a number of potential explanations that might reconcile these sets of data.

Firstly, it was possible the assays we utilised may have been insensitive to subtle changes in receptor function. For real-time analysis of recombinant protein interactions, we are confident that the validated approach taken here would have been sensitive enough to define functional variation, such as the fundamental binding interaction between IGF2 and IGF2R. This was unaltered between Gly1619 and Arg1619. Importantly, we have also shown that the competitive binding between mannose 6-phosphate and IGF2 binding was also unaltered. As IGF2R cycles between the endoplasmic reticulum, Golgi and the pre-lysosomal compartment, it was possible that modified function may have occurred as a result of either altered trafficking, distribution or proteolysis (Ghosh et al. 2003). It is well established that the trafficking and distribution functions of IGF2R depend on the cytoplasmic domain that is remotely located with respect to 1619 , which meant that it would have been highly unlikely that Gly1619Arg would have altered trafficking. However, several important non-synonymous polymorphisms of membrane receptors have functional effects that were related to altered protein half-life. For example, the chemokine receptor CCR2-Val64Ile polymorphism resulted in protein with prolonged half-life that had explained the delayed progression to AIDS in HIV infected humans with 64Ile (Nakayama et al. 2004). In addition, deletion of Phe508 of the CFTR gene leads to cystic fibrosis because of altered folding, stability and plasma membrane half-life (Sharma et al. 2004). Here, we directly addressed this question and performed quantitative pulse-chase and flow cytometry experiments that suggested that Gly1619Arg did not significantly alter the rate of protein production, processing, proteolysis and membrane distribution. The only remaining functional mechanism that we did not directly test was the potential interaction of residue 1619 with domain 12, and the potential for indirect modification of IGF2R dimerisation (Kreiling et al. 2005). We have previously detected dimerisation of 1-4\% of recombinant domain 11-12 and 11-13 using analytical ultracentrifugation, corroborating our observation of structural juxtaposition of domain 12 in crystals and the data obtained using epitope tagged IGF2R (Kreiling et al. 2005, Brown et al. 2008). Ligand binding does not alter the ability of IGF2R to dimerise, but dimerisation may improve the avidity of the receptor for ligands and increase the rate of internalisation (York et al. 1999, Byrd et al. 2000). Detailed examination of our crystal structures confirmed that Gly1619R was remote from the hydrophobic dimerisation surface in domain 12 that involved Pro1755 and Tyr1741, and that there appeared no conformational change in position of 1619 when comparing crystals from domains 11-12 (where there is no dimerisation) with those of 11-13 (where there is dimersiation) (not shown, Brown et al. (2008)). These observations suggested that Gly1619Arg would be unlikely to alter the extent and stability of IGF2R dimerisation, particularly as multiple domain interactions that regulate dimerisation avidity between full length receptors.

Our data leads us to conclude that the Gly1619Arg polymorphism is non-functional. It is possible that there could be interactions with other non-synonymous SNPs. For example, the location of the Gln1696Arg (rs11552587) residue appeared closely localised to Gly1619Arg in the crystal structure (Fig. 8), and may directly interact to modify function. However, this SNP is very rare in the populations examined so far (e.g. 0.009 allelic frequency in the Yoruba) and means that it was unlikely that this interaction would be significant. However, it is possible that in certain populations the rs629849 SNP is in LD with others that could contribute to differential function or expression of the IGF2R gene. Importantly, the SNPs with suggested LD with the

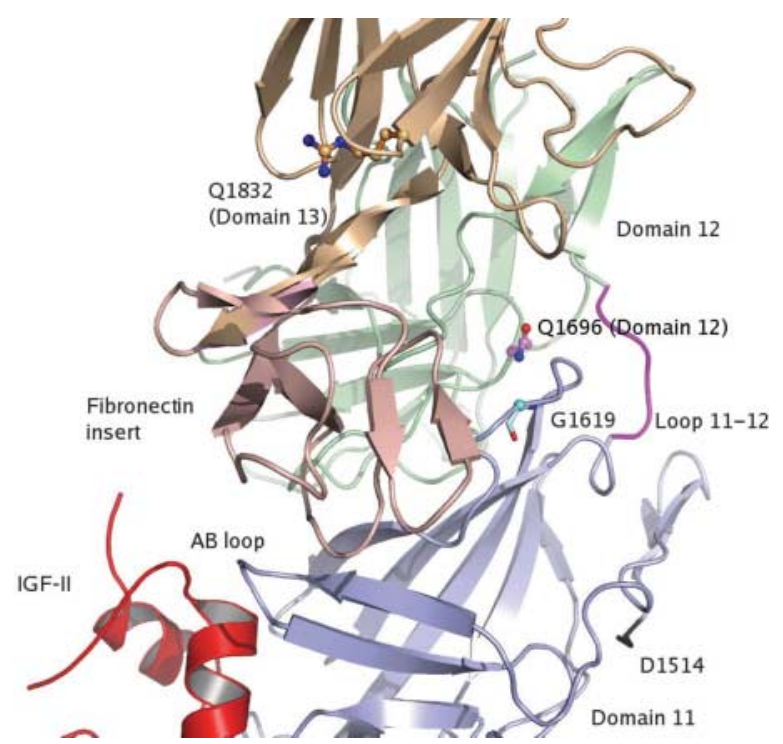

Figure 8 Structural localisation of Gln1696Arg and Gly1619Arg. The rare SNP (rs11552587) results in a non-synonymous polymorphism Gln1696Arg that modifies an amino acid that also locates close to Gly1619Arg in the region between domains 11, 12 and 13. Other potential non-synonymous amino acids are also shown (GIn/Q1832, Asp/D1514), but none are in linkage disequilibrium with rs629849. 
Gly1619Arg polymorphism were in intronic sequences and could possibly affect intron-exon splice sites. Functional associations need not be correlated with exon SNPs, as functional consequences may occur as a result of intron SNPs, for example recently implicated in altered methylation (Savage et al. 2007). Alternatively, other non-synonymous SNPs in other regions of the protein may result in unpredictable functional changes. In order to completely understand the complex function of the IGF2R protein and the effect of genetic polymorphisms on its function, further experimental evaluation of IGF2R polymorphisms are warranted.

\section{Declaration of interest}

The authors declare that there is no conflict of interest that could be perceived as prejudicing the impartiality of the research reported.

\section{Funding}

Supported by Cancer Research UK (C429, C375), Wellcome Trust and NIH. This research was supported (in part) by the Intramural Research Program of the National Institutes of Health, National Cancer Institute, Division of Cancer Epidemiology and Genetics.

\section{Acknowledgements}

We thank James Brown, Emily Foulstone, David Barnes and John Crosby for discussion, Cancer Research UK (ABH- C429, EYJ-C375), Wellcome Trust UK (MC-082352) and an Algerian Ministry of Higher Education Scholarship (DR) for funding.

\section{References}

Barrett JC, Fry B, Maller J \& Daly MJ 2005 Haploview: analysis and visualization of LD and haplotype maps. Bioinformatics 21 263-265.

Brown J, Esnouf RM, Jones MA, Linnell J, Harlos K, Hassan AB \& Jones EY 2002 Structure of a functional IGF2R fragment determined from the anomalous scattering of sulfur. EMBO Journal 21 1054-1062.

Brown J, Delaine C, Zaccheo OJ, Siebold C, Gilbert RJ, van Boxel G, Denley A, Wallace JC, Hassan AB, Forbes BE et al. 2008 Structure and functional analysis of the IGF-II/IGF2R interaction. EMBO Journal 27 265-276.

Byrd JC, Devi GR, de Souza AT, Jirtle RL \& MacDonald RG 1999 Disruption of ligand binding to the insulin-like growth factor II/mannose 6-phosphate receptor by cancer-associated missense mutations. Journal of Biological Chemistry 274 24408-24416.

Byrd JC, Park JH, Schaffer BS, Garmroudi F \& MacDonald RG 2000 Dimerization of the insulin-like growth factor II/mannose 6-phosphate receptor. Journal of Biological Chemistry 275 18647-18656.

Christofori G, Naik P \& Hanahan D 1994 A second signal supplied by insulin-like growth factor II in oncogene-induced tumorigenesis. Nature 369 414-418.

Clairmont KB \& Czech MP 1989 Chicken and Xenopus mannose 6-phosphate receptors fail to bind insulin-like growth factor II. Journal of Biological Chemistry 264 16390-16392.
Clairmont KB \& Czech MP 1991 Extracellular release as the major degradative pathway of the insulin-like growth factor II/mannose 6-phosphate receptor. Journal of Biological Chemistry 266 12131-12134.

Conover CA, Bale LK, Overgaard MT, Johnstone EW, Laursen UH, Fuchtbauer EM, Oxvig C \& van Deursen J 2004 Metalloproteinase pregnancy-associated plasma protein A is a critical growth regulatory factor during fetal development. Development 131 $1187-1194$.

Cui H, Cruz-Correa M, Giardiello FM, Hutcheon DF, Kafonek DR, Brandenburg S, Wu Y, He X, Powe NR \& Feinberg AP 2003 Loss of IGF2 imprinting: a potential marker of colorectal cancer risk. Science 299 1753-1755.

Davis SJ, Ward HA, Puklavec MJ, Willis AC, Williams AF \& Barclay AN 1990 High level expression in Chinese hamster ovary cells of soluble forms of CD4 T lymphocyte glycoprotein including glycosylation variants. Journal of Biological Chemistry 265 10410-10418.

De Souza AT, Hankins GR, Washington MK, Orton TC \& Jirtle RL 1995 $\mathrm{M} 6 \mathrm{P} / \mathrm{IGF} 2 \mathrm{R}$ gene is mutated in human hepatocellular carcinomas with loss of heterozygosity. Nature Genetics 11 447-449 issn: 1061-4036.

Delaglio F, Grzesiek S, Vuister GW, Zhu G, Pfeifer J \& Bax A 1995 NMRPipe: a multidimensional spectral processing system based on UNIX pipes. Journal of Biomolecular NMR 6 277-293.

Dennis PA \& Rifkin DB 1991 Cellular activation of latent transforming growth factor beta requires binding to the cation-independent mannose 6-phosphate/insulin-like growth factor type II receptor. PNAS 88 580-584.

Devi GR, De Souza AT, Byrd JC, Jirtle RL \& MacDonald RG 1999 Altered ligand binding by insulin-like growth factor II/mannose 6-phosphate receptors bearing missense mutations in human cancers. Cancer Research 59 4314-4319.

Foulstone E, Prince S, Zaccheo O, Burns JL, Harper J, Jacobs C, Church D \& Hassan AB 2005 Insulin-like growth factor ligands, receptors, and binding proteins in cancer. Journal of Pathology 205 $145-153$.

Frazer KA, Ballinger DG, Cox DR, Hinds DA, Stuve LL, Gibbs RA, Belmont JW, Boudreau A, Hardenbol P, Leal SM et al. 2007 A second generation human haplotype map of over $3 \cdot 1$ million SNPs. Nature 449 851-861.

Garrone S, Radetti G, Sidoti M, Bozzola M, Minuto F \& Barreca A 2002 Increased insulin-like growth factor (IGF)-II and IGF/IGF-binding protein ratio in prepubertal constitutionally tall children. Journal of Clinical Endocrinology and Metabolism 87 5455-5460.

Ghosh P, Dahms NM \& Kornfeld S 2003 Mannose 6-phosphate receptors: new twists in the tale. Nature Reviews. Molecular Cell Biology 4 202-212.

Hancock MK, Haskins DJ, Sun G \& Dahms NM 2002a Identification of residues essential for carbohydrate recognition by the insulin-like growth factor II/mannose 6-phosphate receptor. Journal of Biological Chemistry 277 11255-11264.

Hancock MK, Yammani RD \& Dahms NM $2002 b$ Localization of the carbohydrate recognition sites of the insulin-like growth factor II/mannose 6-phosphate receptor to domains 3 and 9 of the extracytoplasmic region. Journal of Biological Chemistry 277 47205-47212.

Hankins GR, De Souza AT, Bentley RC, Patel MR, Marks JR, Iglehart JD \& Jirtle RL 1996 M6P/IGF2, receptor: a candidate breast tumor suppressor gene. Oncogene 12 2003-2009.

Harper J, Burns JL, Foulstone EJ, Pignatelli M, Zaina S \& Hassan AB 2006 Soluble IGF2 receptor rescues Apc $(\mathrm{Min} /+)$ intestinal adenoma progression induced by Igf2 loss of imprinting. Cancer Research 66 1940-1948.

Ito Y, Koessler T, Ibrahim AE, Rai S, Vowler SL, Abu-Amero S, Silva AL, Maia AT, Huddleston JE, Uribe-Lewis S et al. 2008 Somatically acquired hypomethylation of IGF2 in breast and colorectal cancer. Human Molecular Genetics 17 2633-2643.

Kaku K, Osada H, Seki K \& Sekiya S 2007 Insulin-like growth factor 2 (IGF2) and IGF2 receptor gene variants are associated with fetal growth. Acta Paediatrica 96 363-367. 
Kalscheuer VM, Mariman EC, Schepens MT, Rehder H \& Ropers HH 1993 The insulin-like growth factor type-2 receptor gene is imprinted in the mouse but not in humans. Nature Genetics $\mathbf{5}$ 74-78.

Kiess W, Thomas CL, Greenstein LA, Lee L, Sklar MM, Rechler MM, Sahagian GG \& Nissley SP 1989 Insulin-like growth factor-II (IGF-II) inhibits both the cellular uptake of beta-galactosidase and the binding of beta-galactosidase to purified IGF-II/mannose 6-phosphate receptor. Journal of Biological Chemistry 264 $4710-4714$.

Kiess W, Thomas CL, Sklar MM \& Nissley SP 1990 Beta-galactosidase decreases the binding affinity of the insulin-like-growth-factorII/mannose-6-phosphate receptor for insulin-like-growth-factor II. European Journal of Biochemistry 190 71-77.

Killian JK, Oka Y, Jang HS, Fu X, Waterland RA, Sohda T, Sakaguchi S \& Jirtle RL 2001 Mannose 6-phosphate/insulin-like growth factor 2 receptor (M6P/IGF2R) variants in American and Japanese populations. Human Mutation 18 25-31.

Kolonel LN, Altshuler D \& Henderson BE 2004 The multiethnic cohort study: exploring genes, lifestyle and cancer risk. Nature Reviews. Cancer 4 519-527.

Kong FM, Anscher MS, Washington MK, Killian JK \& Jirtle RL 2000 RLM6P/IGF2R, is mutated in squamous cell carcinoma of the lung. Oncogene 19 1572-1578.

Kreiling JL, Byrd JC \& MacDonald RG 2005 Domain interactions of the mannose 6-phosphate/insulin-like growth factor II receptor. Journal of Biological Chemistry 280 21067-21077.

Linnell J, Groeger G \& Hassan AB 2001 Real time kinetics of insulinlike growth factor II (IGF-II) interaction with the IGF-II/mannose 6-phosphate receptor: the effects of domain 13 and $\mathrm{pH}$. Journal of Biological Chemistry 276 23986-23991.

Ludwig T, Eggenschwiler J, Fisher P, D'Ercole AJ, Davenport ML \& Efstratiadis A 1996 Mouse mutants lacking the type 2 IGF receptor (IGF2R) are rescued from perinatal lethality in Igf2 and Igflr null backgrounds. Developmental Biology 177 517-535 issn: 0012-1606.

Nakayama EE, Tanaka Y, Nagai Y, Iwamoto A \& Shioda T 2004 A CCR2V64I polymorphism affects stability of CCR2A isoform. AIDS $\mathbf{1 8}$ 729-738.

Ong K, Kratzsch J, Kiess W, Costello M, Scott C \& Dunger D 2000 Size at birth and cord blood levels of insulin, insulin-like growth factor I (IGF-I), IGF-II, IGF-binding protein-1 (IGFBP-1), IGFBP-3, and the soluble IGF-II/mannose-6-phosphate receptor in term human infants, The ALSPAC study team. Avon longitudinal study of pregnancy and childhood. Journal of Clinical Endocrinology and Metabolism 85 4266-4269.

Packer BR, Yeager M, Burdett L, Welch R, Beerman M, Qi L, Sicotte H, Staats B, Acharya M, Crenshaw A et al. 2006 SNP500Cancer: a public resource for sequence validation, assay development, and frequency analysis for genetic variation in candidate genes. Nucleic Acids Research 34 D617-D621.

Petry CJ, Ong KK, Wingate DL, Brown J, Scott CD, Jones EY, Pembrey ME \& Dunger DB 2005 Genetic variation in the type 2 insulin-like growth factor receptor gene and disparity in childhood height. Growth Hormone and IGF Research 15 363-368.
Savage SA, Woodson K, Walk E, Modi W, Liao J, Douglass C, Hoover RN \& Chanock SJ 2007 Analysis of genes critical for growth regulation identifies Insulin-like Growth Factor 2 Receptor variations with possible functional significance as risk factors for osteosarcoma. Cancer Epidemiology Biomarkers E Prevention 16 1667-1674.

Sharma M, Pampinella F, Nemes C, Benharouga M, So J, Du K, Bache KG, Papsin B, Zerangue N, Stenmark H et al. 2004 Misfolding diverts CFTR from recycling to degradation: quality control at early endosomes. Journal of Cell Biology 164 923-933.

Vranken WF, Boucher W, Stevens TJ, Fogh RH, Pajon A, Llinas M, Ulrich EL, Markley JL, Ionides J \& Laue ED 2005 The CCPN, data model for NMR spectroscopy: development of a software pipeline. Proteins 59 687-696.

Wang ZQ, Fung MR, Barlow DP \& Wagner EF 1994 Regulation of embryonic growth and lysosomal targeting by the imprinted Igf2/Mpr gene. Nature 372 464-467.

Williams C, Rezgui D, Prince SN, Zaccheo OJ, Foulstone EJ, Forbes BE, Norton RS, Crosby J, Hassan AB \& Crump MP 2007 Structural insights into the interaction of insulin-like growth factor 2 with IGF2R domain 11. Structure 15 1065-1078.

Wutz A, Theussl HC, Dausman J, Jaenisch R, Barlow DP \& Wagner EF 2001 Non-imprinted Igf2r expression decreases growth and rescues the Tme mutation in mice. Development 128 1881-1887.

Wylie AA, Pulford DJ, McVie-Wylie AJ, Waterland RA, Evans HK, Chen YT, Nolan CM, Orton TC \& Jirtle RL 2003 Tissue-specific inactivation of murine M6P/IGF2R. American Journal of Pathology 162 321-328.

Xu Y, Goodyer CG, Deal C \& Polychronakos C 1993 Functional polymorphism in the parental imprinting of the human IGF2R gene. Biochemical and Biophysical Research Communication 197 747-754.

Yandell CA, Dunbar AJ, Wheldrake JF \& Upton Z 1999 The kangaroo cation-independent mannose 6-phosphate receptor binds insulinlike growth factor II with low affinity. Journal of Biological Chemistry 274 27076-27082.

York SJ, Arneson LS, Gregory WT, Dahms NM \& Kornfeld S 1999 The rate of internalization of the mannose 6-phosphate/insulin-like growth factor II receptor is enhanced by multivalent ligand binding. Journal of Biological Chemistry 274 1164-1171.

Young LE, Fernandes K, McEvoy TG, Butterwith SC, Gutierrez CG, Carolan C, Broadbent PJ, Robinson JJ, Wilmut I \& Sinclair KD 2001 Epigenetic change in IGF2R is associated with fetal overgrowth after sheep embryo culture. Nature Genetics 27 153-154.

Zaccheo OJ, Prince SN, Miller DM, Williams C, Kemp CF, Brown J, Jones EY, Catto LE, Crump MP \& Hassan AB 2006 Kinetics of insulin-like growth factor II (IGF-II) interaction with domain 11 of the human IGF-II/mannose 6-phosphate receptor: function of CD and $\mathrm{AB}$ loop solvent-exposed residues. Journal of Molecular Biology 359 403-421.

Received in final form 8 January 2009

Accepted 4 February 2009

Made available online as an Accepted Preprint 4 February 2009 